\title{
The Grammatical Explanation of Al-Jundi in The Book of Anwar Al-Misbah Sharh Misbah Al-Mutarrzi
}

\author{
Shahad Yassir Thakir*, Mahmood Khalaf Hamad \\ Department of Arabic, College of Arts, Al Anbar University, Iraq \\ *shahad_yassir@yahoo.com
}

\begin{abstract}
:
This research aims to study the grammatical reasoning methods of Al-Jundi in his book "Anwar alMisbah Explanation" of Misbah Al-Mutarrzi" that we are intending to investigate .The reason that represent as the grammatical cause and its employment, so the search was on three axes, preceded by an introduction, so the first axis dealt with the definition of the reason in the language and the terminology and the emergence of the reason in Arabic grammar, the second axis was devoted to studying the employment of the reason and its types among Arab grammarians. His attitudes towards the author of the text, then a conclusion in which we explained the most important results of the research.
\end{abstract}

Keywords: $\quad$ The Reason; Anwar Al-Misbah; Misbah Al-Mutarrzi; The Grammatical Reasoning; Al-Jundi.

Crossref doi https://doi.org/10.51345/.v32i1.296.g187 


\section{التعليل النحوي عند الجلدي في كتابه أنوار المصابيح شرح مصباح المطرّزي \\ شهد ياسر ذاكر "، أ.م.د. محمود خلف حمد السبهاني \\ قسم اللغة العربية، كلية الآداب، جامعة الأنبار، العراق \\ * shahad_yassir@yahoo.com}

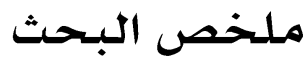

يهدف هذا البحث إلى دراسة منهج التعليل النحوي عند الجندي في كتابه أنوار المصباح شرح مصباح المطرزي الذي نقوم بتحقيقه، فالعلة التي تمثل ركناً أساسياً من أركان القياس وسمة بارزة من سمات الفكر النحوي العربي كانت حاضرة أيها حضور في الفكر النحوي عند الجندي، وقد تتبعنا في هذا البحث العلة النحوية وتوظيفها، فكان البحث على محاور ثلاثة، مسبوقة بمقدمة، فالمحور الأول تناولنا تعريف العلة في اللغة والاصطلاح وننأة العلة في النحو العربي، المحور الثاني خُصص لدراسة توظيف العلة وأنواعها عند النحاة العرب، أمّا المحور الثالث فتناولنا فيه منهج الجندي في الترجيح والتعليل وتر جيحات مواقفه من صاحب المتن، ثم خاتمة بينت فيها اهم نتائج البحث.

الكلمات المفتاحيلة: العلة، أنوار المصباح، المصباح للمطرزي، التعليل النحوي، الجندي. 


\section{المقدمة:}

مثّل التعليل سمةً بارزةً في النحو العربي، ومَعْلماً مهاً من معالم منهجه، والاطلاع على كتب النحو يؤكد أن النحو في حقيقته يشكل أحكاماً، وهذه الاحكام لابّد لها من قياس، والعلة من أهم أركان القياس النحوي. وقد كانت العلة لصيقة بالحكم النحوي منذ كتاب سيبويه (ت 180هـ)، واخذت تتسع شيئاً فشيئاً، وزاد الاهتمام بها، بحيث انشغل النحاة بها أكثر من انشغالهم بالنحو نفسه. أضف الى ما تقدم انه لم يكن هناك منهجْج يحدد ويؤُطر التعليل بأنه محكوم بلغة بني تميم أو أهل الحجاز أو قيس أو طيئ أو غيرهم. على الرغم من أنّ اغلب النحاة يدعون إلى لهجة قريش باعتبارها لهجة حاكمة أو صحيحة، نراهم يرجعون في كثير من الشو اهد الى غيرها من اللهجات العربية، فعلى العموم ان مصدر مادة التعليل كانت نسبية الى حد كبير في اختيار اللهجة التي ينطلق منها النحوي. ومها يكن من شيء، فقد كانت نشأة العلة وليدة استقر اء العرب للغتهم. ومن هذا المنطلق ارتأينا أن نبحث عن التعليل النحوي عند الجندي في كتابه انوار المصابيح شرح مصباح المطرزي لنقف على منهجه في التعليل وترجيح العلل عنده، ومن الله التوفيق والسداد.

\section{1 توظيف العلل}

\section{العلّة لغيةً:}

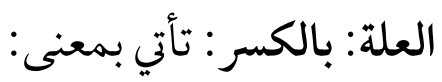

- - "المرض: عَلّ يعلّ واعتلّ، أي: مرضَ فهو عليلّ، وأعلّه الله، و لا أعلّك الله، أي لا أصابك بعلّة" (1). - - الحدث يشغل صاحبه عن حاجته، كأن تلك العلّة صارت شغلاً ثابتاً منعه من شغله الأوّل"(2). - السّبب: "هذا علّةٌ هذا، أي سببُ "(3)، وفي حديث عائشة - رضي الله عنها - (فكان عبد الرّمن (4) يضرب رجلي بعلّة الرّاحة؛ أي: بسببها، يظهر أنه يضرب جنب البعير برجله وإنما يضرب

$$
\text { رجلي.... (5) مهو وهو ما يهمنا هنا. }
$$


وقال الكفوي: "العلّة لغة: عبارة عن معنى يحل بالمحل فيتغير به حال المحل، ومنه سمي المرض علقاً. وهي ما يتوقف عليه الشيء"(6).

\section{العلّة فِّ الاصطلاح النّحوي":}

تعددت تعريفات العلم)ء للعلة النحوية انطلاقًا من المدلول اللغوي، فهي عند الرّماني: " تغيير المعلول عَّما كان عليه"(7). وعرفها الجرّّجاني بقوله: "هي ما يتوقف عليه وجود الشّيء ويكون خارجًا مؤثرًا فيه"(8).وعرّفها الدّكتور مازن المبارك بـ"الوصف الّذي يكون مظنّة وجه الحكمة في اتخاذ الحكمى"(9). وعرّفها الدّكتور علي أبو المكارم: "بأنها السبب الّذي تحقق في المقيس عليه فأوجب له حكماً، وتحقق في المقيس أيضاً فألحق به فأخذ حكمه"(10). وبيّن الدّكتور تمام حسان أن الفرق بين العلّة والسّبب فرق في التأثير، "فالحكم يدور مع العلّة وجوداً وعدماً، ولكنه لا يدور مع السّبب"(11). والعلة من أركان القياس، فالقياس في عرف النحاة يعني "تقـدير الفرع بحكم الأصل، وقيل هو حمل فرع على أصـل بعلة"(12). ولابد لكل قياس من أربعة أركان يقوم عليها، قال أبو البركات الأنباري: "ولا بد لكل قياس من أربعة أشياء: أصل، وفرع، وعلة، وحكم" (13).

فالأصل هو المقيس عليه، والفرع هو المقيس، والحكىم هو ما ينتقل من المقيس عليه إلى المقيس، والعلة هي السبب الذي من أجله استحق المقيس حكم المقيس عليه(14). فالنائب عن الفاعل مثلاً استحق الرفع قياسًا على الفاعل، فالأصل هو الفاعل، والفرع هو النائب عن الفاعل، والحكم هو الرفع، والعلة الجامعة هي الإسناد(15).

\section{2.}

نشأة التعليلات النحوية كانت مرافقةً لنشأة النحو متزامنةً معه، يقول الدكتور صاحب أبو جناح: "إن عملية بناء النحو ونشأته رافقتها نشأة العلل التي يفسر بها النحاة الظواهر اللغوية والنحوية ويردون بها على تساؤلات الدارسين للغة ونصوصها و المعنيين بأمرها"(16). ويروي أبو القاسم الزجاجي عن بعض شيوخه 
"أنّ الخليل بن أحمد رحمه الله - سئل عن العلل التّي يعتل بها في النّحو، فقيل له: عن العرب أخذتها أم

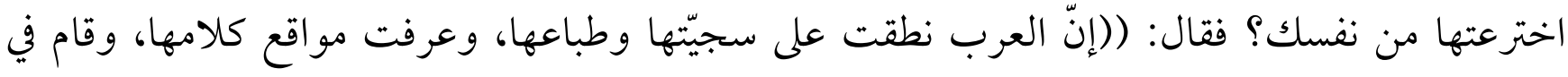

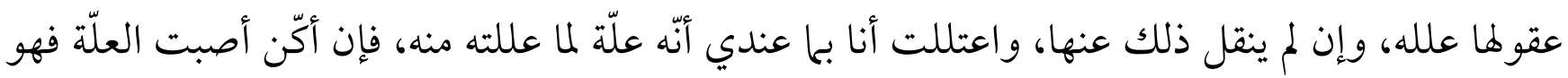

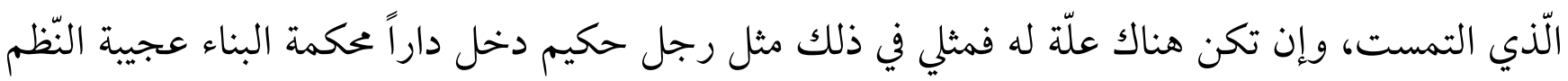

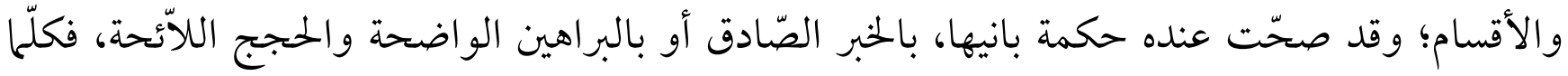
وقف هذا الرّجل في الدّار على شيء منها قال: إنّّا فعل هذا هكذا لعلّة كذا و كذا، ولسبب كذا وكذا، سنحت له له وخطرت بباله محتملة لذلك، فجائز أن يكون الحكيم الباني للدّار فعل ذلك للعلّة التّي ذكرها هذا الّذي دخل

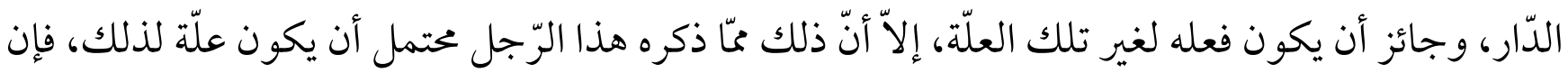

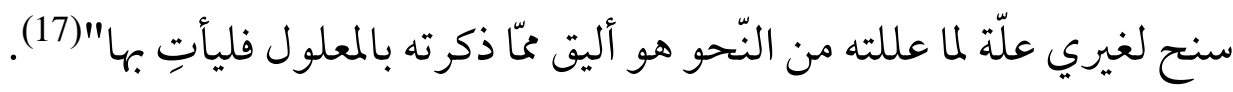

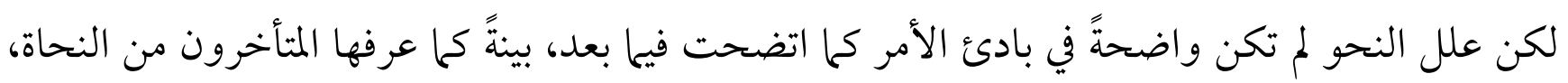
ولكنها كانت تفهم من سياق الكلام، وتلتمس من نمط الحديث (18). ولعلّ عبد الله بن أبي اسحاق الحضرمي (ت 117 هــ) من أوائل النّحاة الّذين اهتموا بالتعليل وبلغوا الغاية فيه

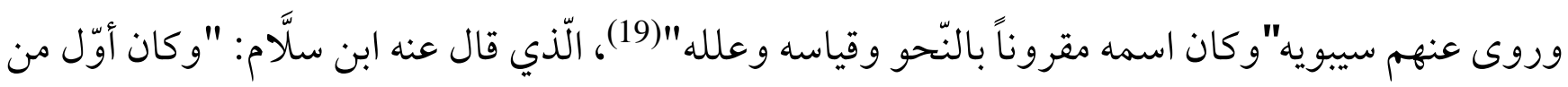

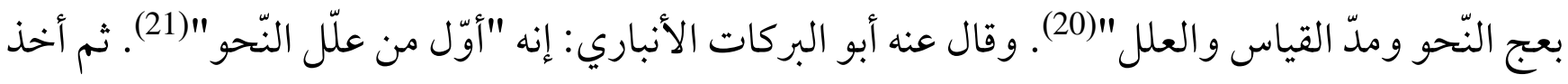

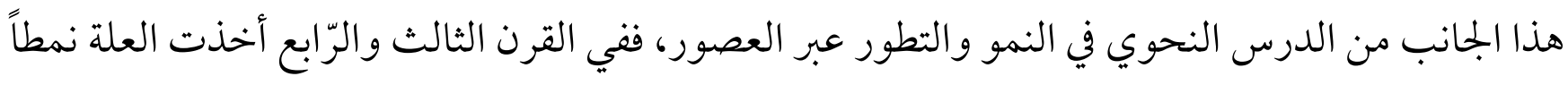

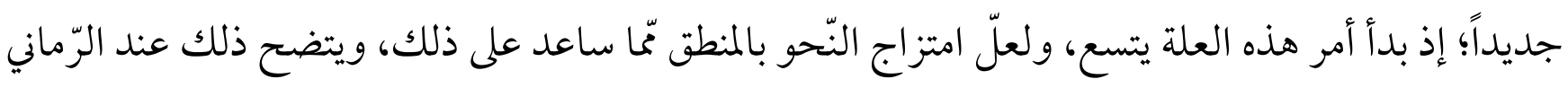
من علماء القرن الرّابع الذي كان يمزج النّحو بالمنطق حتى قال فيه أبو علي الفارسي: "إن كان النّحو ما يقوله الرّمّاني فليس معنا منه شيء، وإن كان النّحو ما نقوله فليس معه منه شيء بـ (22).

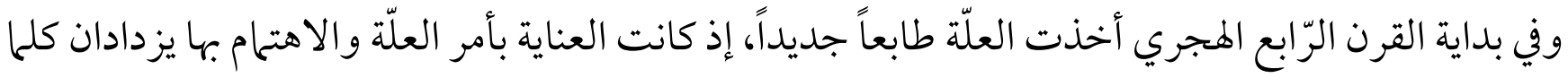
تقدم الزّمن بالنّحويين، ولعلّ من أبرز الكتب الّتي وصلت إلينا في العلّة كتاب (الإيضاح في علل النّحو) 
للزّجّاجي (ت 337هـ)، ويرى الزّبّاجي أنّ علل النحو "إنما هي مستنبطة أوضاعاً ومقاييس، وليست كالعلل الموجبة للأشياء المعلول بها"(23). وهكذا استمر اهتمام علملء اللغة القدماء بالعلل دراسة وتحليلا وبيانا لحكمة العرب في لغتهم، إلى أن أفردوا

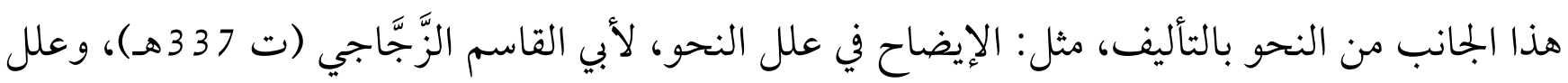
النحو، لمحمد بن عبد الله بن العباس، أبو الحسن، ابن الوراق (ت

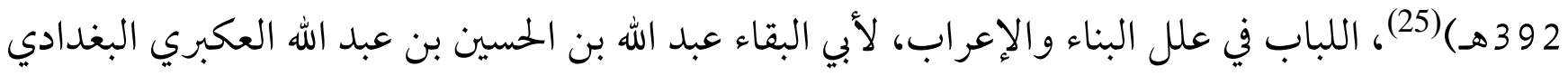
محب الدين (ت 616 هـ) (26)، وغيرها الكثير.

\section{3. توظيف العلة:}

توظيف العلة أو أثر العلة في الأحكام النحوية، فقد استخدمها النحاة للترجيح عند الاختلاف، ومنهم الجنْدي في هذا الكتاب، فقد أثبت أن (نعم وبئس) فعلان بطريق التعليل حيث قال: "الفصل الأول: في فعلي المدح

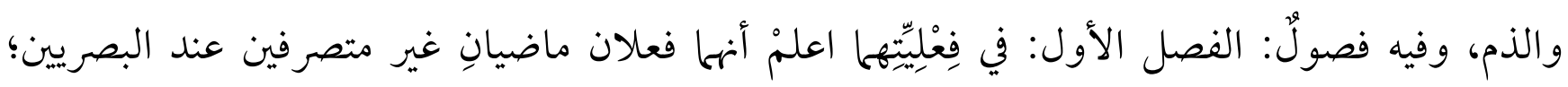

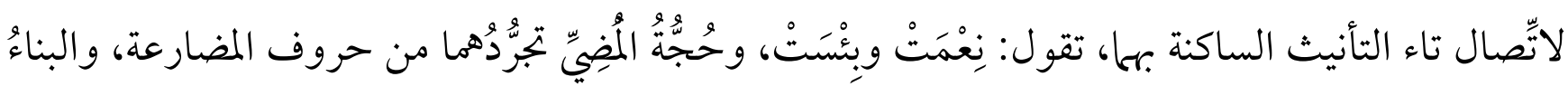

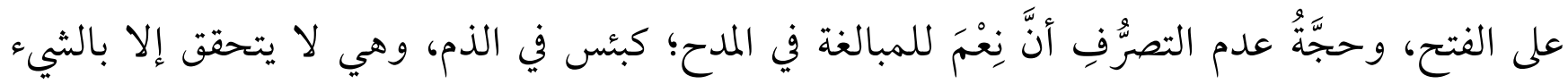

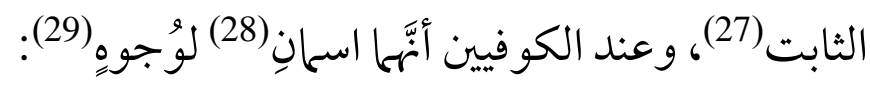

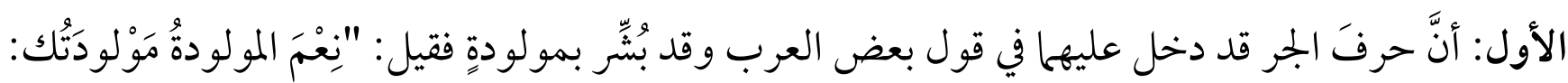

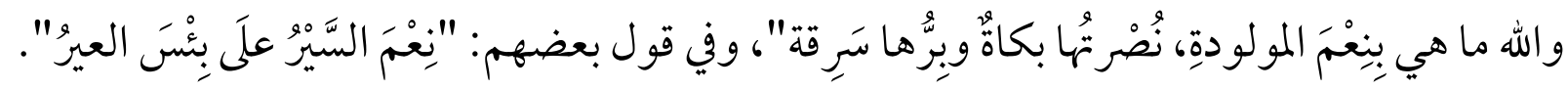

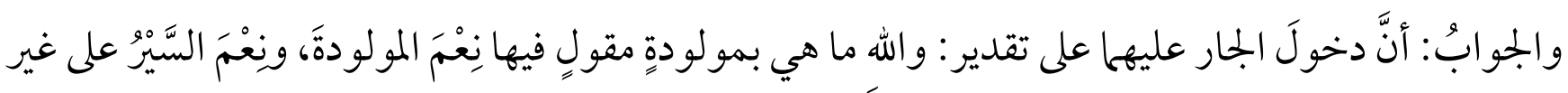

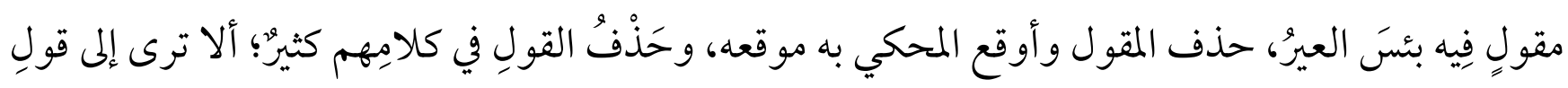

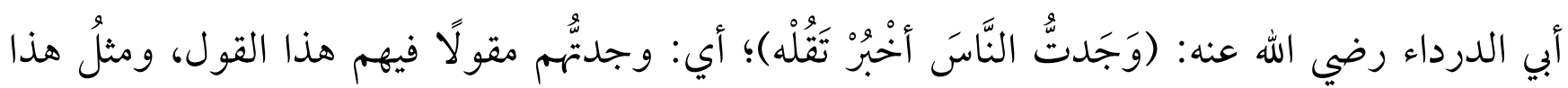

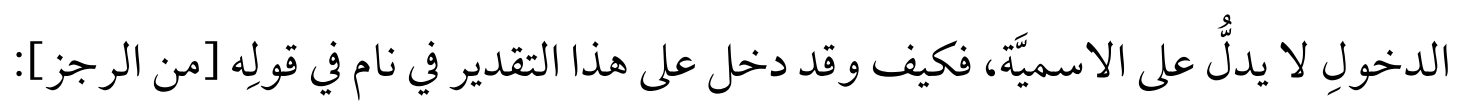




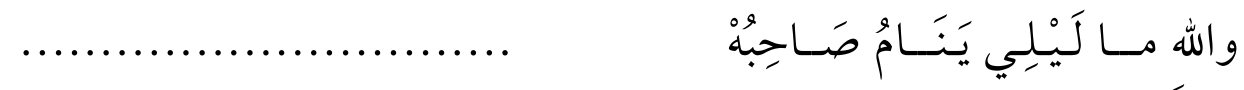

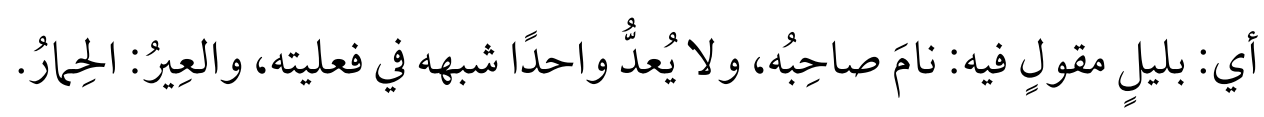

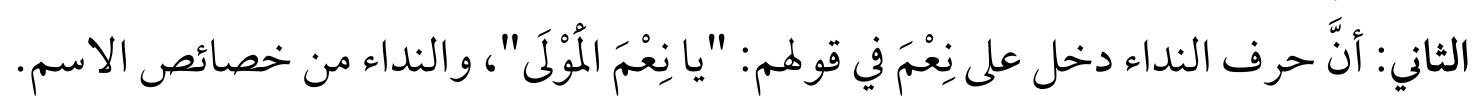

والجِواب: أن المنادى ححذوف، و التقدير: يانِعْمَ المُوْلَّ أَنْتَ.

الثالث: أنها لمُ يقترنا بزمانِ، لا يحسن أن يقول: نِعْمَ الرجل أمس ولا غدًا، فلو كان فعلين لاقترنا به. و الجمو ابُّ: أنَّها لغاية الملحح والذم، فيلزم من هذا أن ثُعل دلالتها مقصودة على زمان الحال؛ لأنَّ الملدح والذم إنها يكو نان بها هو موجوددو في الممدوح والمذموم لا بها كان فزال، و لا بها يكون في زمان الاستقبال"(30). كان الحَنْي كثيرًا ما يعلل ويوجه كلام المطرزي في المصباح، ومن أمثلة ذلك قوله: "العلامة السادسة: تاء التأنيث(31)، كما في أمثلته الثلاثة، وقوله (الساكنة): احتر ازًا عن تاء نحو: كريمةٍ، وضاربةٍ"(32).

\section{4. أنواع العلل}

ذكر الزجاجي في كتاب (الإيضاح في علل النّحو) أن علل النّحويين على ثلاثة أضرب "علل تعليمية، وعلل قياسية، وعلل جدلية نظرية(33).

1. العلة التعليمية (أو العلة الاولى): هذه العلة في جوهرها تفسير للواقع اللغوي اذ ترصدها الدراسة الوصفية للظواهر اللغوية ، فتتبين العلاقات التركيبية للصيغ والمفردات في الجمل والاساليب وتتضح الوظائف النحوية. والذي حدا بالنحاة للأخذ بهذه العلة رغبتهم في تبسيط القو اعد النحوية فبها يتوصل الى كلام العرب. ومن هذا النوع من العلل قولنا: (إنّ زيداً قائم)، فِإنْ قيل: بم نُصب زيد ؟ قلنا : بـ(إنّ)، لأنّا تنصب الاسم وترفع الخبر وهكذا سمعت عن العرب. 2. العلة القياسية (أو العلة الثانية): وهذه تحاول ان تربط بين الظواهر المختلفة بملاحظة ما بينها من صلات، وأخذ النحاة بها سعياً لطرد الاحكام. ومثالها أنْ يقال لمن قال نصبت زيداً بـ(إنّ)، في قوله (إنّ زيداً قائم): ولم وجب أنْ تنصب (إن) الاسم ؟ فالجمواب على ذلك بمقتضى هذه العلة، أن يقول: لأنها 
وأخو اتها ضارعت الفعل المتعدي الى مفعول، فحملت عليه فأعملت إعماله لما ضارعته فهي تشبه من الافعال ما قدم مفعوله على فاعله. 3. العلة الجدلية النظرية (أو العلة الثالثة): أما هذه العلة فتبدأ بعد العلتين السابقتين وهي تعليل لهما، وتأييد لهما عن طريق التبرير المنطقي؛ إذ إنّا تأتي من الاحساس بضرورة منطقة الظواهر والقواعد والعلل جميعاً. وهي على ما مثلنا به أعلاه أن يقال: من أي جهة شابهت هذه الحروف الافعال ؟ولم شابهت ما قدم مفعوله على فاعله وهو ليس باصل؟ وما الذي دعا الى الحاقها بالفرع دون الاصل؟؟... الخ ، فالجواب الذي يعتل به عن أي من هذه المسائل هو علة ثالثة وداخل في الجمدل والنظر.

\section{5 ـ منهج الجندي يف الترجيح والتعليل}

التَّْْيح: رَجَّحَ أحدَ القولين على الآخر: أي غلبه، من رجحان الميزان"(34). و الترجيح لا يكون إلا عند التعارض(35)، أو وجود أقوال في المسألة تحتاج إلى مرجح، وقد اعتمد النحاة في ترجيحاتهم واختياراتهم للآراء النحوية على مجموعة من المبادئ والأصول التي تقوي ما ذهبوا إليه، وكان من أهم ما اعتمدوا عليه ما يسمى بـ (أصول النحو)، ولعل السماع والقياس أهم ما في هذه الأصول فقد أشبعو ا بها كتبهم، وذلك لكونها أساس هذا العلم. واستخدم الجَنْدي بعض الصيخ للدلالة على الترجيح منها: الاكتفاء بأشهر الأقوال في المسألة، أو التصريح باختياره، أو التصريح بتصحيح أو تصويب أحد الأقوال مثل (الصحيح)، أو التنصيص على تحسين قول بأحد صيغ التحسين مثل (الأَّهلى) و(الأحسن)، أو التصريح بقول مع النص على ضعف غيره، أو التصريح بقوله: قال أصحابنا، أو مذهب أصحابنا. التصريح بالاختيار فمنها قوله في أنواع المؤنث: "و الحقيقيٌّ أقوى، ولذا امتنع في حال السعة: جاء هندُ، وجاز: طلع الشمس، وإن كان التأنيث هو المختار"(36). أما التصريح بالصحة فمنها قوله: "فأما قولهم: دخلتُ الدارَ، فمذهب أبي عمر الجرمي فيه أنه متعدِّ، فينتصب الدارَ انتصاب المفعول به؛ نحو: بنيتُ الدارَ، ومذهب الأكثرين أنه فعل لازم، وكان الأصل أن يقال: دخلتُ 
في الدارِ، إلا أن حرف الجر حذف بطريق التوسُع، وهذا هو الصحيح، والدليل على هذا من وجهين: أحدهما:

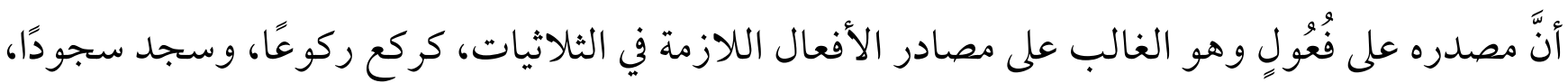

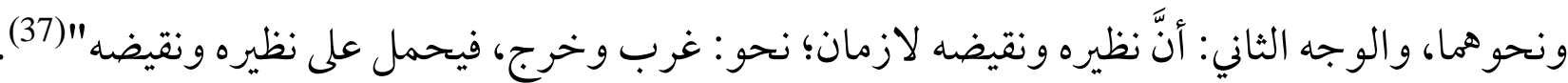

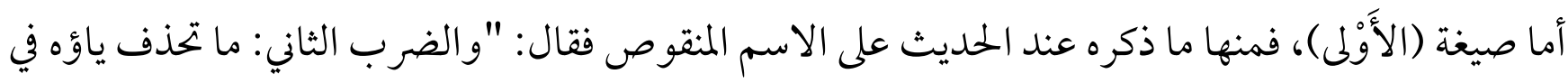
حالتي الرفع والجر، وذلك عند دخول التنوين؛ نحو : جاءني قاضٍ، ومررتُ بقاضٍ، وإنما حذفت الياء لالتقاء الساكنين (38): الياء الساكنة والتنوين، وكان حذف الياء أولى من حذف التنوين لوجهين (39):

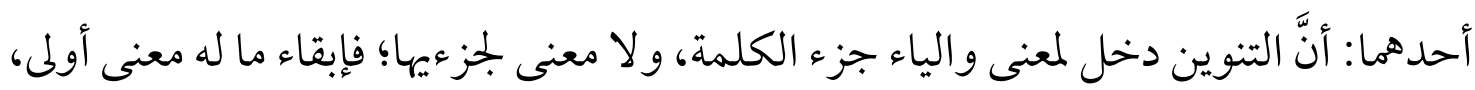
والثاني: أن الياء لو حذفت ففي اللفظ يبقى ما يدل عليها وهو الكسر بخلاف التنوين، فإبقاء ما لا دلالة عليه

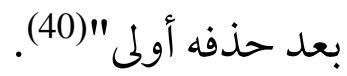

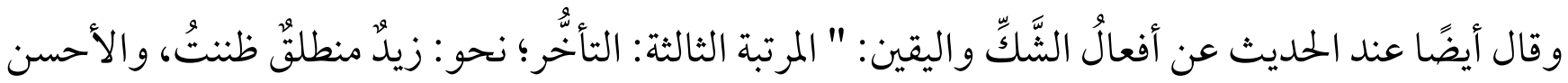

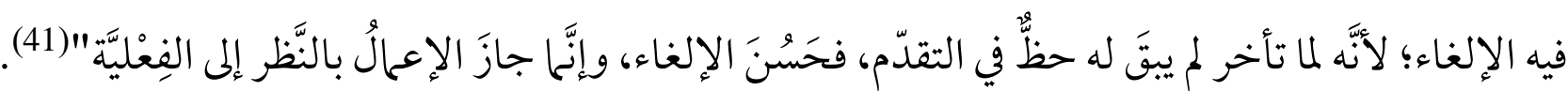

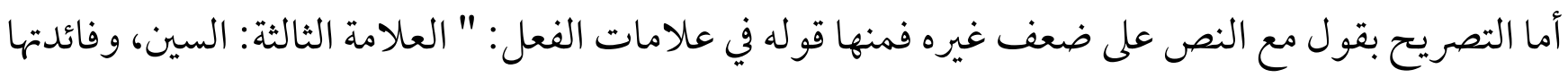

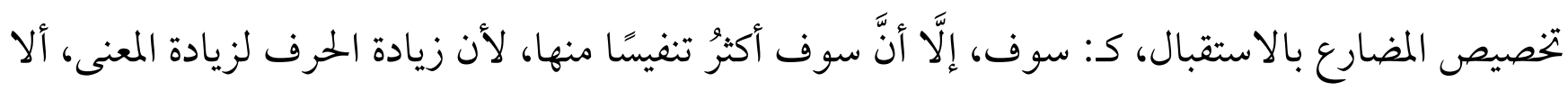
ترى إلى ذا وذاك وذلك، فإن الأول للقريب، والثاني للمتوسط، والثالث للبعيد. وهما خختصان بالمضارع، وكل

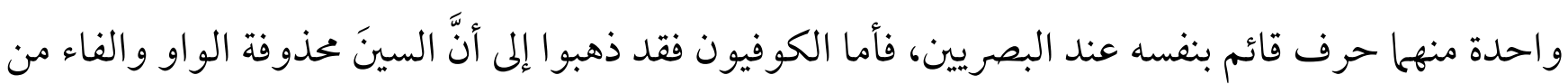
سوف، ولكن عدم دخول الحروف تحت التصرف يؤذن بفساد مذهبهم" (42).

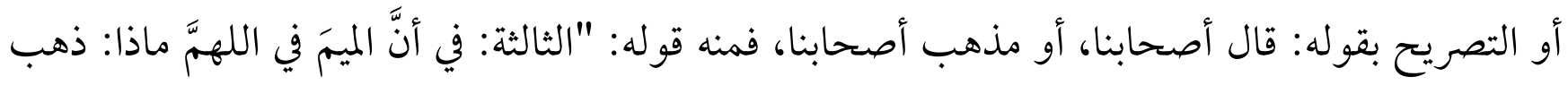

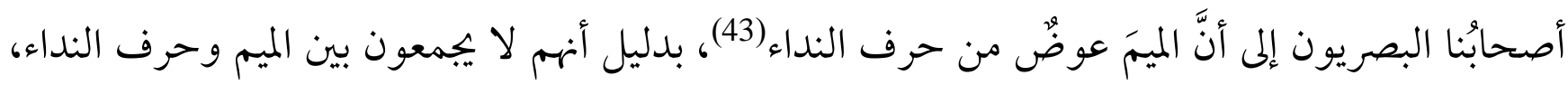

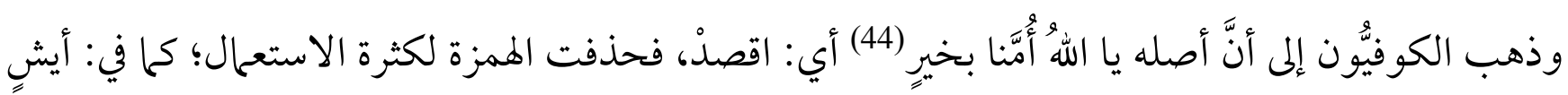

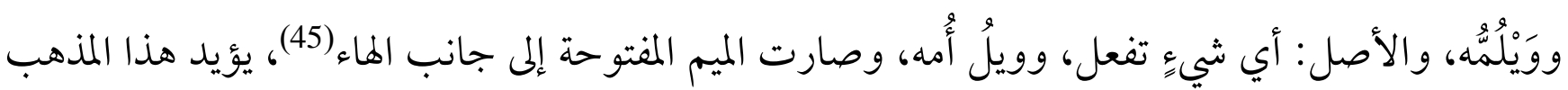

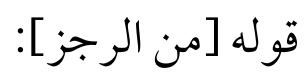




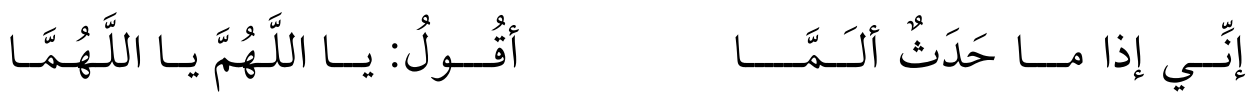

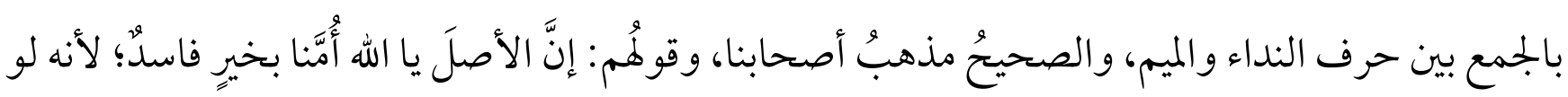

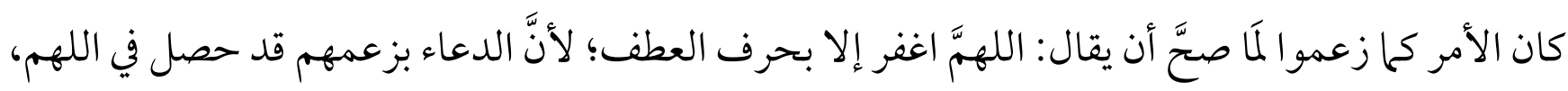

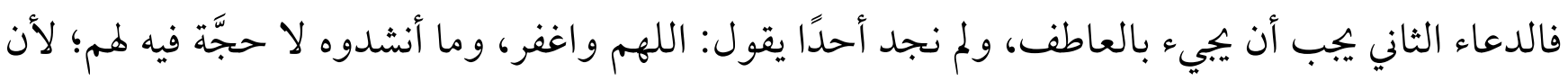

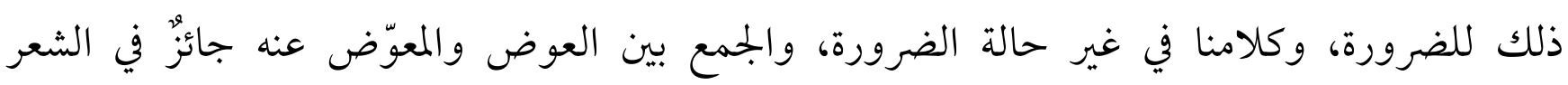
للضرورة(46)؛ ألا ترى إلى قوله [من الطويل]:

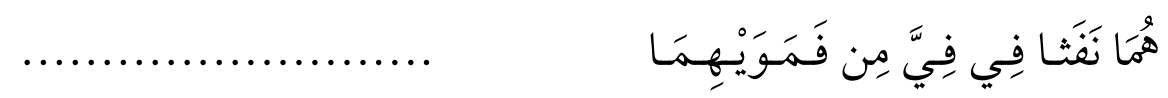

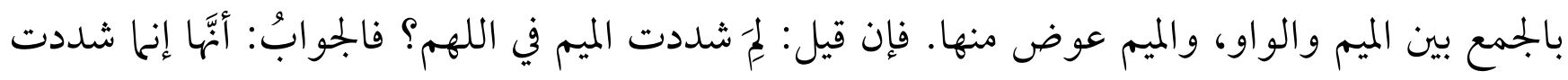
ليجيء العوض على لفظ المعوض عنه عددًا (47).

6. أسس اختياره هِّ الترجيح

\section{1 ـ البعـد التكلف والتقدير:}

ومن ذلك اختياره في إعراب الأسماء الستة الحروف الإعراب بالحروف معرضًا عن باقي الأقوال التي ذكرها النحاة في إعرابها(48)، فقال: "وهي تعرب بالحروف إذاب كانت مضافة، والعلة في ذلك أنها شابهت المثنى المئه

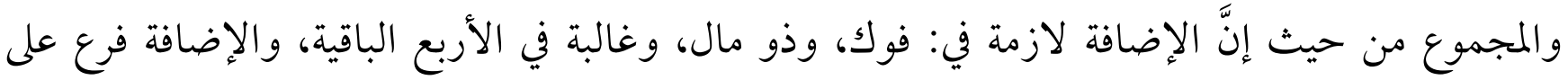

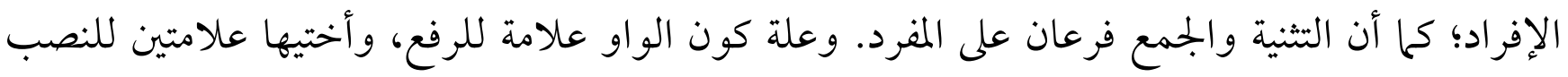

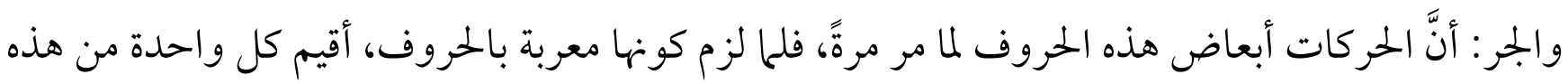
الحروف مقام بعضها"(49). وهنا نجد أن الجُندي ترك جميع الأقوال التي قيلت في إعراب الأسماء الستة ولم يعتمد إلا ما رأه راجحا عنده، وقدم علته لذلك. 


\section{2.قياس الشبـه :}

ومن ذلك ترجيحه لكون حروف المد واللين في المثنى والجمع حروف إعراب، وإعراضه عن ذكر باقي الأقوال في المسألة(50) حيث قال: "المسألة الثالثة: أن الألف في مسلمان حرفُ إعراب، وفيه دليل على الإعراب بمنزلة الدال المرفوعة في: جاءني زيدُّ؛ ألا ترى أنك إذا قلت: جاءني مسلم|ن، يفهم منه أنه مرفوع، وإذا أسقطت الألف بطل معنى الاسم؟ وإذا قلت جاءني زيذ، بالدال الساكنة، لا يستفاد منه الإعراب، ولا يبطل معنى الاسم بإسقاطك الحركة، ويبطل معناه بإسقاط الدال، فلو كان الألف في مسلم|ن بمنزلة الدال المتجردة من الرفعة لما استفيد الإعراب بقولك مسلم|ن؛ كما لا يستفاد إذا سكّنت دال زيد، ولو كان بمنزلة الرفعة المتجردة لما بطل معنى الاسم بإسقاط الألف؛ كما لا يبطل المعنى بإسقاط الحركة من زيد، فعلم أن الألف في (مسلم|ن) بمنزلة الدال المرفوعة من زيد، في أنها حرف إعراب، وفيها دليل على الإعراب؛ كالدال المرفوعة من زيد في: جاءني زيدُ، وكذا الياء والو او في: (مسلمَيْنِ)، و(مسلمِينَ)، و (مسلمُونَ)"(51). ومنه أيضًا ترجيحه صرف الأعجمي الثلاثي ساكن الوسط مثل (دعْد)، وأشار إلى الترجيح بكونه الأكثر، فقال: " الاسم الثلاثي المؤنث لا يخلو من أن يكون ساكن الأوسط أو متحركه، فقي الأول الصرفُ وتركُه، أمَّا الصرف- وهو الأكثر - فلصيرورة الاسم بمنزلة ما ليس فيه إلا سبب واحد بمعادلة خفة لفظه بالسكون ثقل أحد السبيين، و أمَّا ترك الصرف فعلى الظاهر "(52). فعلة ترجيحه أنه صار بمنزلة ما ليس فيه إلا سببا واحدا وهو العجمة هنا، والعجمة سبب ضعيف، ثم إنه أشبه الأوزن العربية القصيرة بكونه ساكن الوسط؛ فلذا أصبح خفيفا فاحتمل الصرف. وهذا هو ما يطلق عليه قياس الشبه. ومن ذلك أيضًا قوله: "الثالثة: في أنَّ الميمَ في اللهَّمَ ماذا: ذهب أصحابُنا البصريون إلى أنَّ الميمَ عوضٌ من

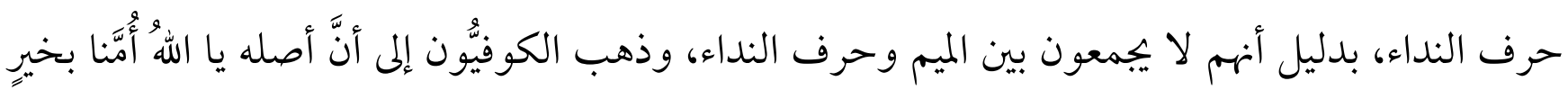

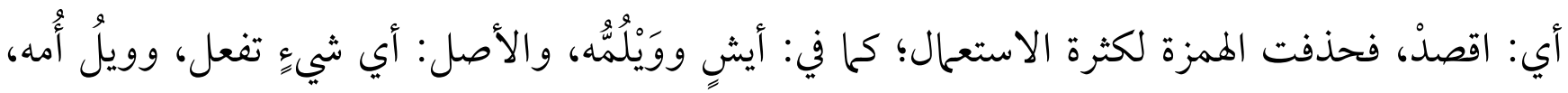
وصارت الميم المفتوحة إلى جانب الهاء، يؤيد هذا المذهب قوله [من الرجز]:

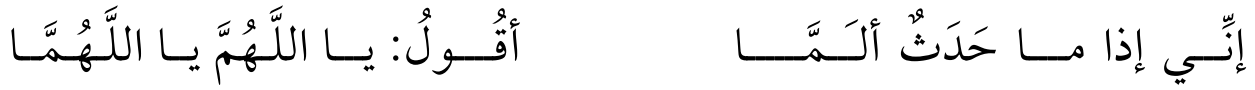


بالجمع بين حرف النداء والميم، والصحيح مذهبُ أصحابنا، وقولُم: إنَّ الأصلَ يا الله أُمَّنَا بخيرِ فاسدُّ؛ لأنه لو

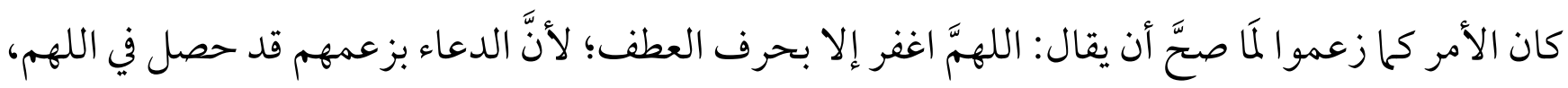

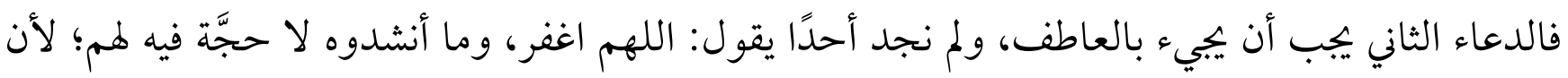

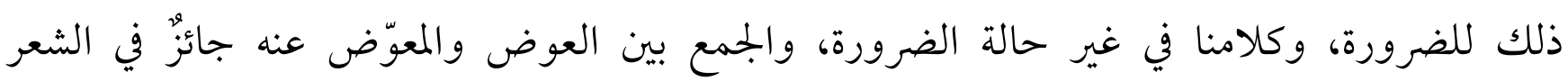
ل ل لضضرورة" (53).

ومن أيضًا قوله: "المسألة الرابعة: أنك إذا ألحقت ضمير المتكلم بأواخر هذه الحروف فلك أن تقول في إنَّ،

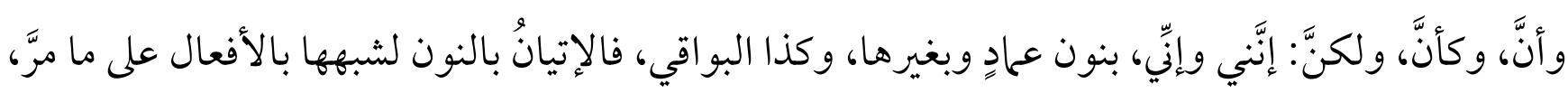
وترك النون لاجتماع ثلاث نوناتٍ، وقيل المحذوفة في إني من النونات الثلاث في إنني هي الأولى؛ لسكونها،

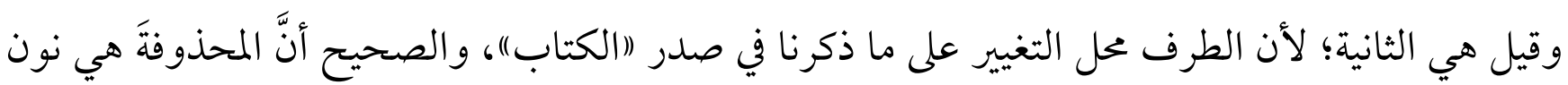

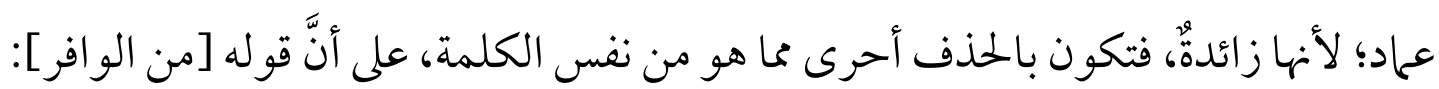

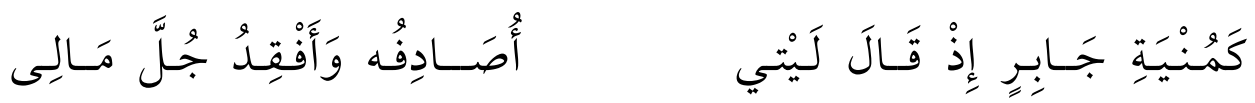
ينادي بأن الصحة لهذا القول لا لغيره"(54).

\section{3. تضعيف غير الوجه المراد:}

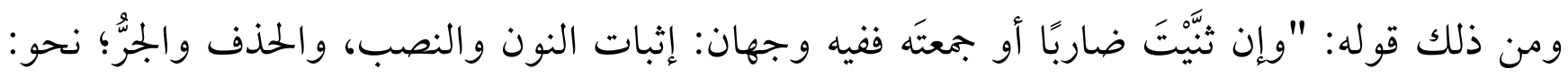

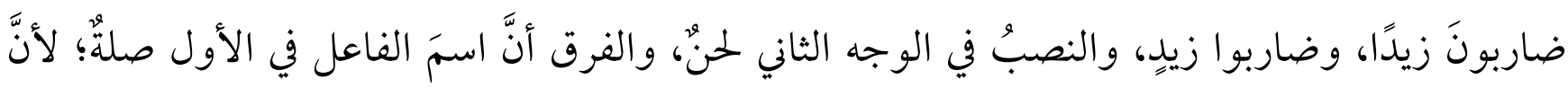
الضاربَ بمعنى الذي ضرب، فاستطيل الاسم، فجاز النصب مع الحذف، بخلاف اسم الفاعل في الثاني"(55). ومن ذلك قوله: "فأما انجزام الجزاء ففيه أقوال:

القول الأول: أنّ (إنْ) مع فعل الشرط يجزمان الجزاء؛ إذ لا انفصال بين إنْ وفعل الشرط، فإذا احتيج إلى الجزاء كانا بمجموعهم) يقتضيانه، فيشتركان في عمل الجزم فيه أيضًا. 
القول الثاني: أن الجازم للجزاء هو إنْ؛ لأنها في اقتضائها الشرط والجزاء سواء، ولهذا سمي حرف الجزاء، وقد عملت في الشرط فتعمل في الجزاء. القول الثالث: أنّ إنْ تعمل في الشرط، وفعل الشرط يعمل في الجزاء؛ لأن فعل الشرط يقتضي الجزاء، وهو أقرب إليه من الحرف، فكان عمله أولى. القول الرابع: أن الجزاء مبني على الوقف؛ لأن إعراب المضارع كان لوقوعه موقع الأسماء، ولم يقع الجزاء موقع الأسماء. القول الخامس: وهو قول الكوفيين-: أنه مجزوم على الجواز؛ لأنه مجاور لفعل الشرط، فيحمل عليه في الجزم؟

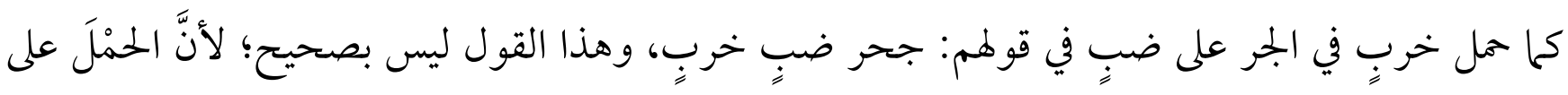
الجوار قليل نزر، فيقتصر فيه على السماع. والقول المختار: هو الأول؛ أما القول الثاني، فلأن إنْ من الجوازم وهي ضعيفة فيفة، فلا تعمل هذه الكلمة في

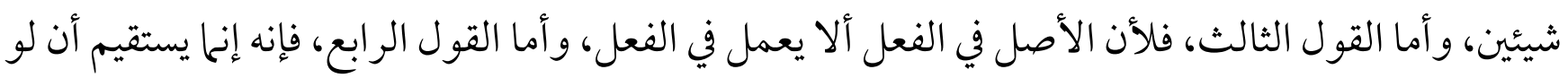
كان وقوعه موقع الأسماء لازمًا له في كل موضع؛ لاستحقاقه الإعراب، وليس بلازم؟ ألا ترى أن المضارع يجزم بالجازم، وينصب بالناصب، وما بعد الجازم والناصب ليس بموضع للاسم، وهو وهذه الكلمة أصل في عمل

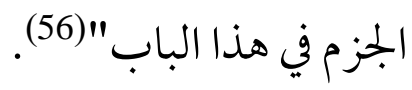

\section{4. اتباع جمهور المذهب البصري:}

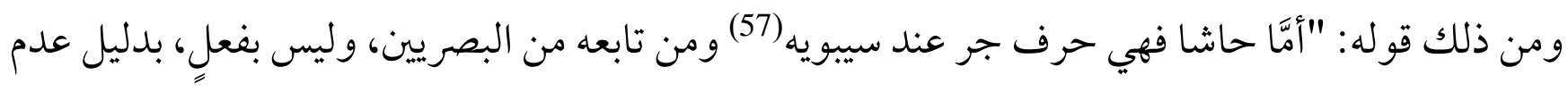

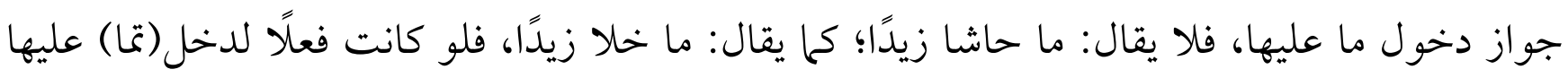

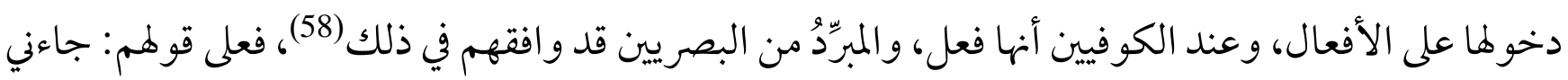
القوم حاشا زيدًا بمعنى جعلوا زيدا في حشًا منهم؛ أي: في جانب؛ كقوله لمن الطن الطويل]:

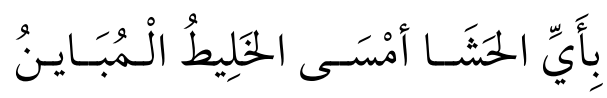


بمعنى: فارق بعضهم زيدًا، وهم في ذلك وجوهُ:

الأول: أنه يتصرف، والتصرف من خصائص الأفعال؛ ألا ترى إلى قول النابغة [من البسيط]: وَلاَ أَرَى فَاعِلاً فِي النَّاسِ يُشْبِهُهُ

فلو كان حرفًا لما قبلت التصرف. والجمواب: أن قوله: "أحاشي" مأخوذًا من لفظ حاشا أخْذَ بسمل من بسم الله، وهلل من لا إله إلا الله، وحمل من الحمد لله، وسبحن من سبحان الله، وحولق من لا حول ولا قوة، وإن كانت هذه الأشياء لا تتصرف، فعلم أن ما ذكره ليس بحجة (59). الوجه الثاني: أنَّ الحذف يدخله، والحذف في الفعل لا في الحرف؛ ألا تراهم قالو ا: حاش لله بحذف اللام، وإلى

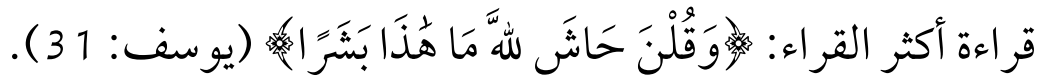

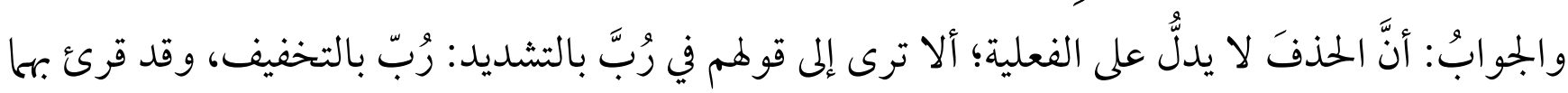
قوله تعالى: الوجه الثالث: أنَّ لام الجر تعلقت بها في قولهم حاش لله، وحرفُ الجر يتعلق بالفعل لا بالحرف. والجوابُ: أنَّ

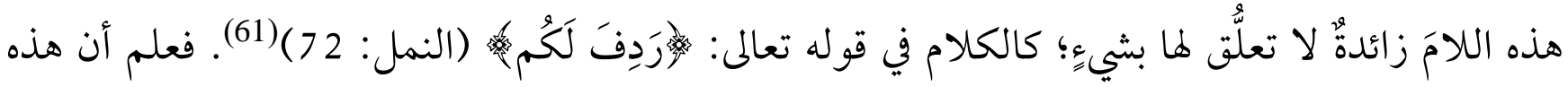

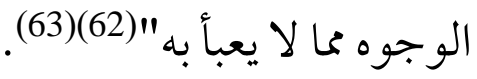
ومن الأسس التي اتبعها في الترجيح التعليل للوجه المختار والرد على ما ينازعه.

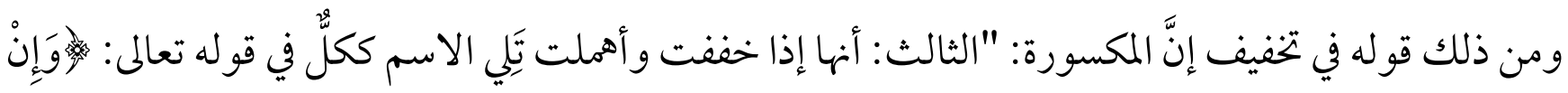

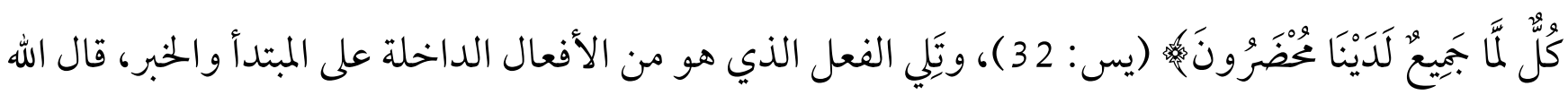

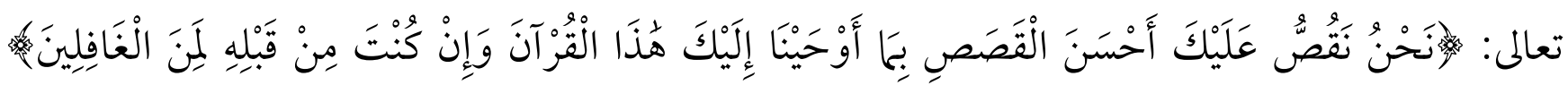

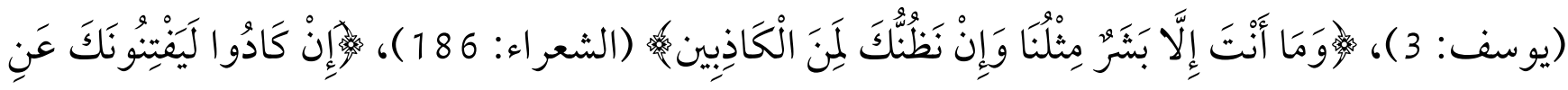

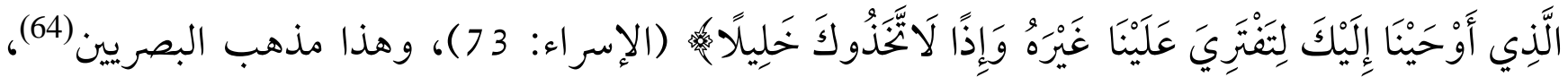
والحجة لهم أنها لمَّا حُرِمَت الدخول على المبتدأ و الخبر، وجب أن تدخل على ما يدخل على المبتدأ والخبر؛ ليكون أصلها مرعيًّ، وعند الكوفيين ييوز دخو لها على غير تلك الأفعال (65)، وأنشدوا قوله [من الكامل]: 


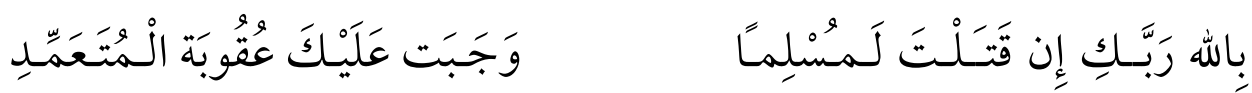

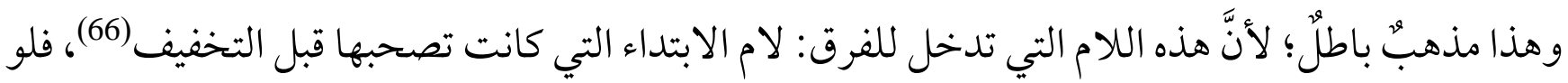

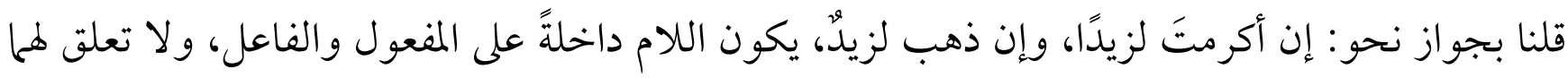

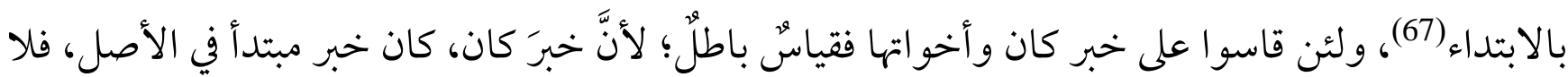
تكون اللام خارجة عن حد الابتداء (68)(69).

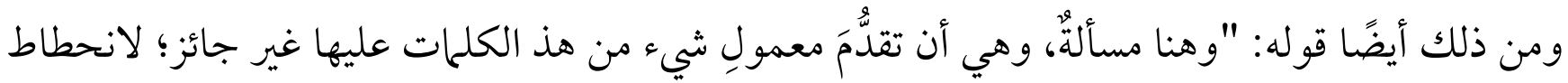

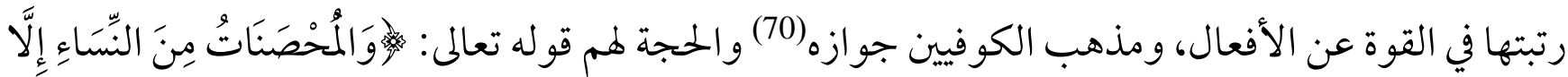

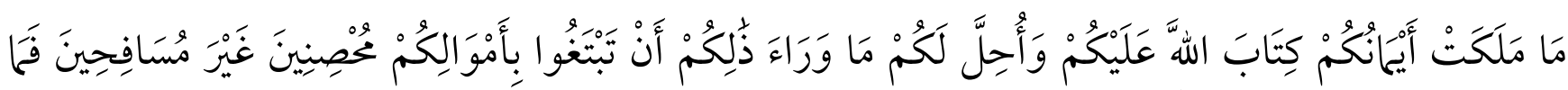

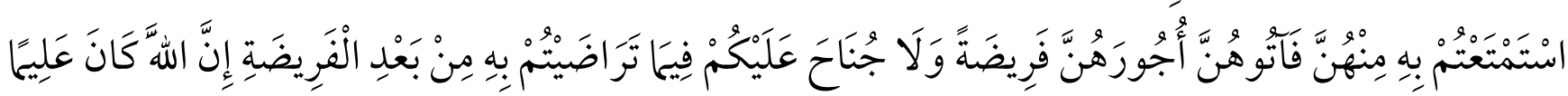

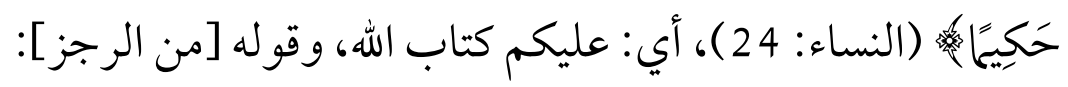

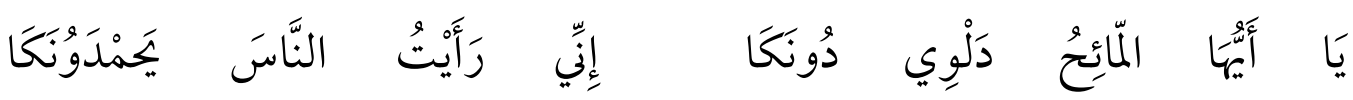

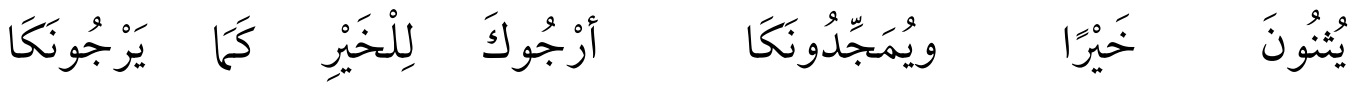
أي: دونك دلوي، وقد كان مر بإنسان على شفير بئر فرمى دلوه فيها، فقال.

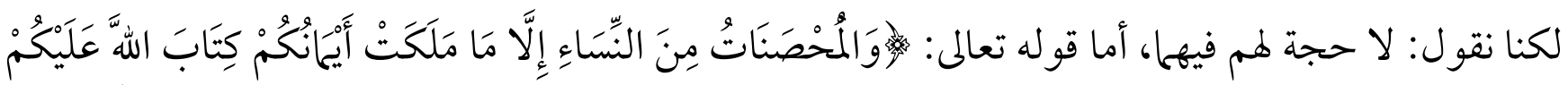

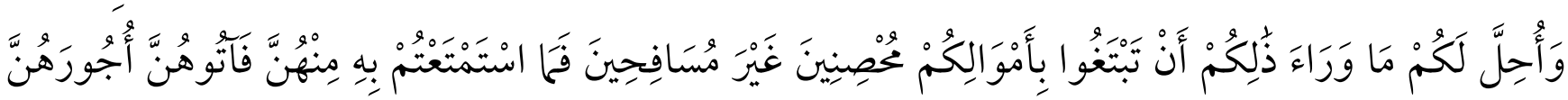

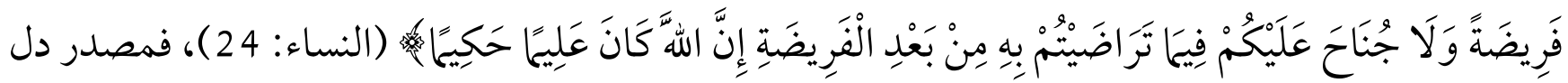

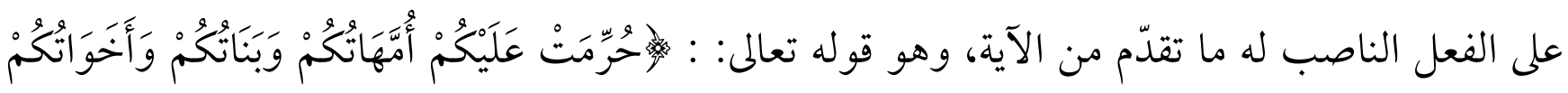

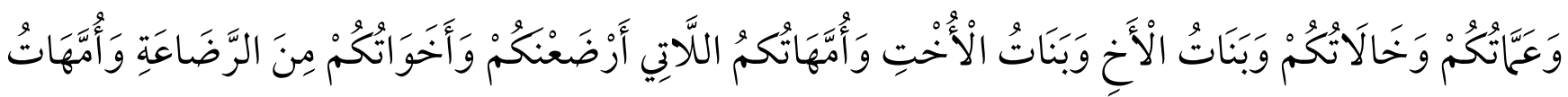

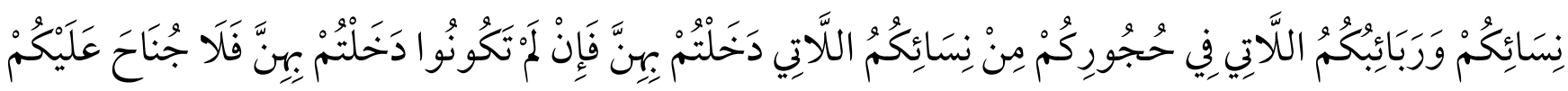

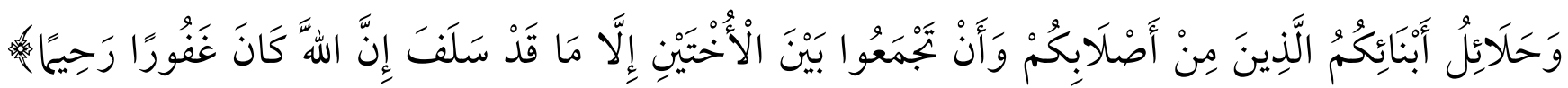
(النساء: 23)، إذ فيه دلالة على أنه مكتوب عليهم، وأما قوله: دلوي دونكا، فدلوي خبر مبتدأ؛ أي: فهذا 
دلوي، أو تقول: هو في موضع نصب بإضمار فعل، على شريطة التفسير، والتقدير : خذ دلوي دونكا، ودونك تفسير لخذ"(72)(72).

هذه هي أشهر الأسس التي بنى عليها الجنْدي ترجيحاته في كتابه أنوار المصابيح عند ذكر الخلافات الواردة

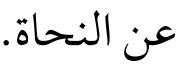

\section{7. ترجيحات مواقفه من صاحب المتن}

عند استعراض شرح الجَنْي على المصباح يظهر أن الجنْدي تابَعَ المطرزي في الغالب الأعم وهذا ما نبه عليه

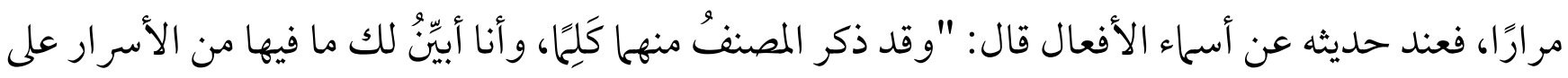
حسب ما ذكر"(73). و وكان يعتمد على المتن في توضيح بعض المعاني ولا يعيد العليق عليها اكتفاء بها ذكره المطرزي في المصباح (المتن) ومن ذلك قوله عند الحديث عن عطف البيان: " وعطف البيان حقه أن يكون اسمًا

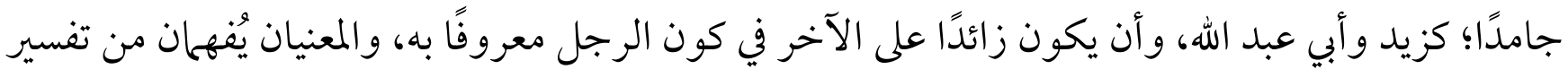
المصنف إياه في المتن، فافهم" (74). بل كان يدافع عن المصنف فيما يبدو أنه نقص، من ذلك قوله في باب الحروف العاطفة: " فإن قيل: ما بالهم

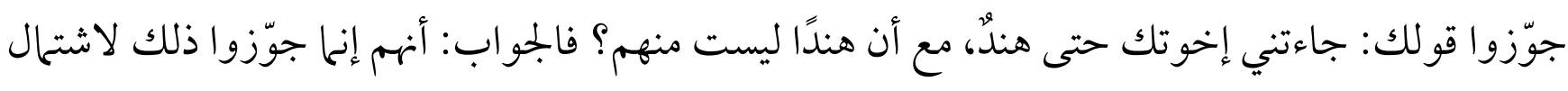

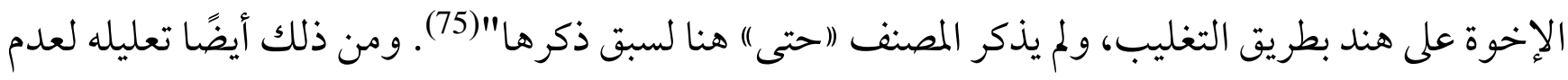
ذكر المطرزي (أما) في حروف العطف بقوله: "وأمّا إما: فبمنزلة أو في وجوهها الثلاثة، تقول: جاءني إما زيد

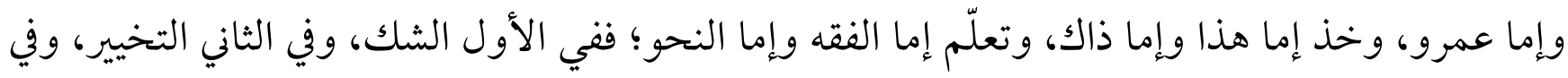

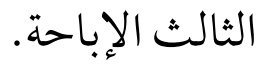

و الفرق بينها أن إما لكونها مذكورة قبل المعطوف عليه يبنى الكلام على المعنى المطلوب منها؛ كما في: جاءني إما

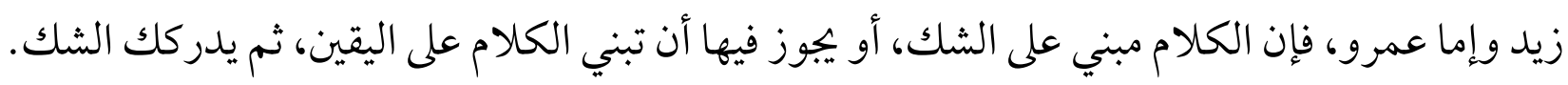

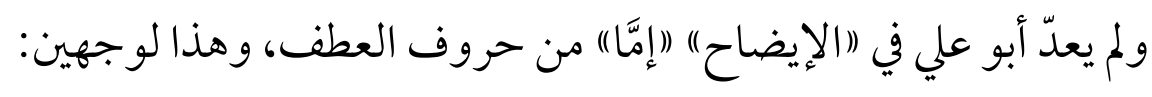


أحدهما: أنك تقول: لقيت إما زيدًا وإما عمروًا، فيأتي تامَّا بين الفعل ومعموله، وهو زيدًا، ولا يعطف معمول

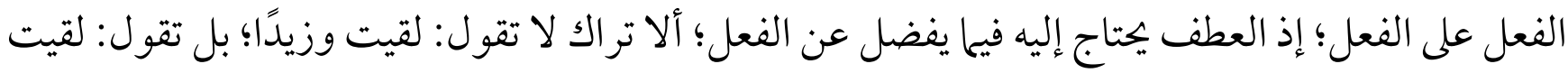

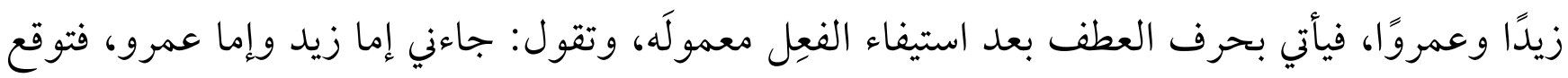
"(إماا) بين الفعل وفاعله، والفاعل كالجزء من الفعل، واقتضاء الفعل للفاعل أشد من اقتضائه للمفعول، وهذا

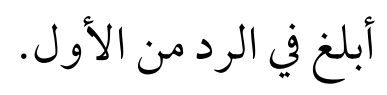

الثاني: أنك تجمع بينها وبين الواو في قولك: جاءني إما زيد وإما عمرو، ولو كانت حرف عطف لما جاز الجمع إنع

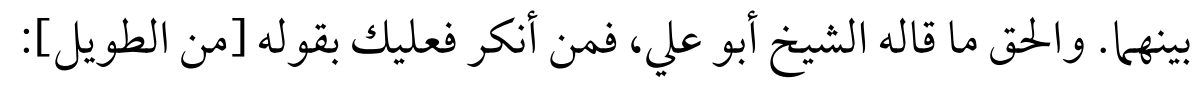

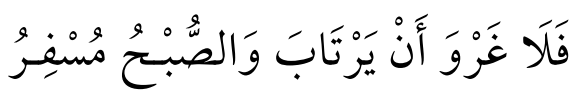

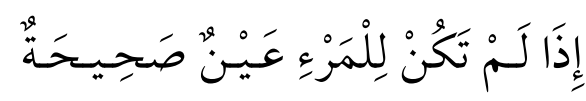

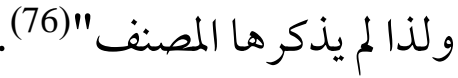

وكان يثني على دقة اختياره للألفاظ الدالة على المعاني الدقيقة، من ذلك قوله: " المقدمة الثانية: أن ذلك البعض

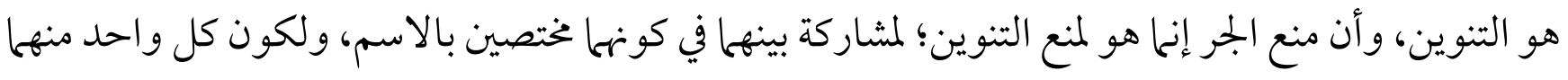

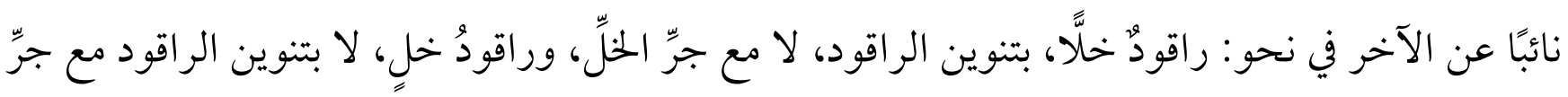

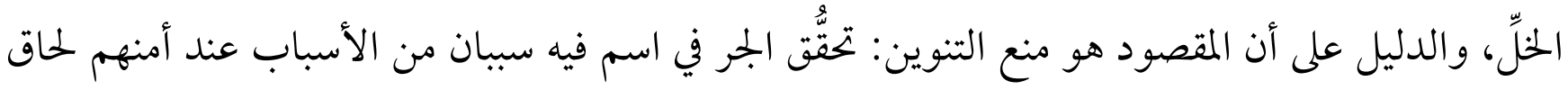
التنوين، كالأممر والحمراء؛ إذ التنوين لا يجامع لام التعريف، وإيثار المصنف كلمة مع على الواو في قوله:

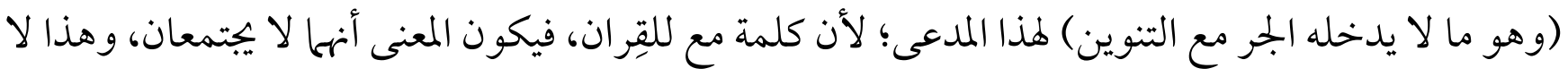

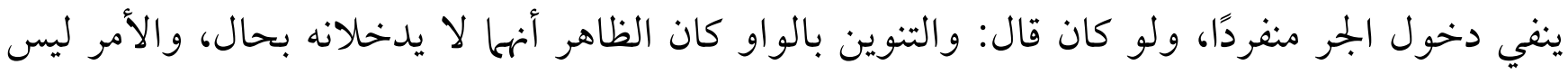
كذلك، فلهذه الفائدة آثر مع على الواو" (77). وقد يخالفه في بعض الأحيان؛ لكنه كان يوضح الأسباب التي دعته إلى هذه المخالفة، وكانت نخالفته له إما

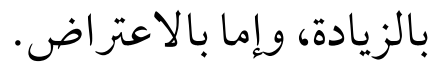
فمن زياداته على المصباح: ما ذكره في باب النداء من زيادة بعض حروف النداء عن التي ذكرها صاحب

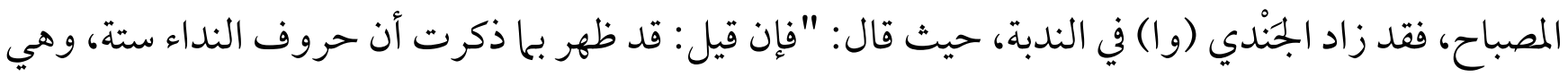


تلك الخمسة و(وا) في الندبة، فما بال المصنف لم يذكر في المتن إلا الخمسة؟ فالجواب: أنَّ المصنفَ إنها ذكر الحروف التي تستعمل في النداء الحتيقي، وتلك الخمسة بهذه المنزلة بخلاف (وا) في الندبة، فإنها غير مستعملة

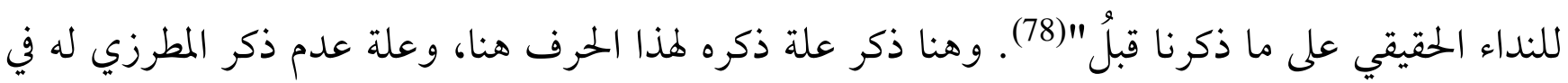
المصباح.

ومن اعتراضه عليه: ما ذكره الجَندي تعليقًا على تقسيم المطرزي للجمل إلى أربعة أقسام فقال: "وقوله

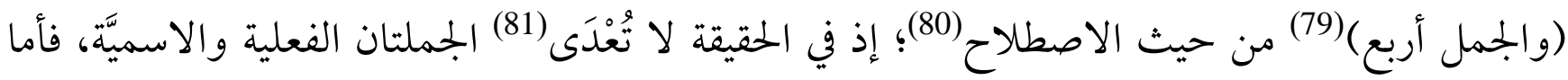

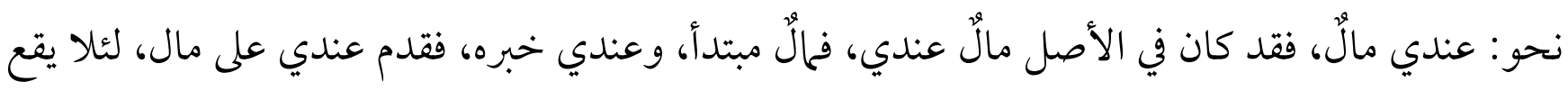

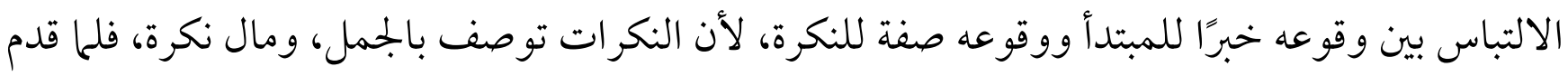
عندي تعيّنت الخبرية، لامتناع تقدم الصفة على الموصوف، والتقدير في (عندي مال): (استقرَّ عندي)، فطرح

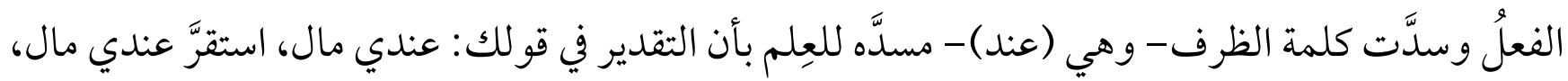
فلما سدَّتْ كلمة الظرف مسدَّ ذلك، سميت ذلك جملة ظرفية.

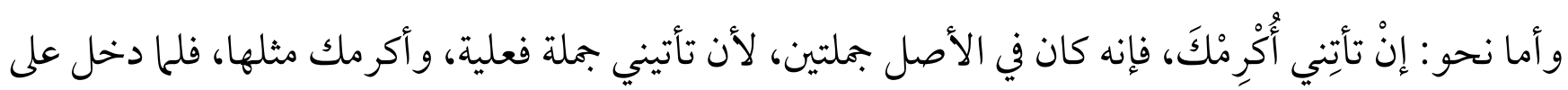

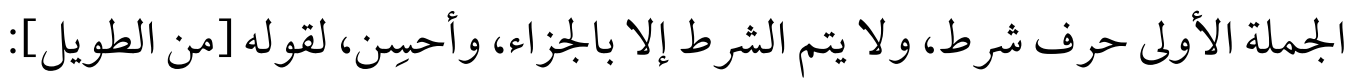

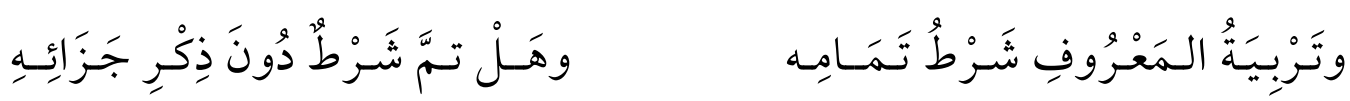
سميت جملة شرطية، لأن صيرورة هاتين الجملتين جملة واحدة بسبب حرف الشرط"(82).

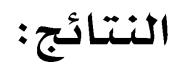
1. نشأت العلة النحوية بالتوازي مع نشوء الدرس النحوي، ووضع احكامه وأصوله وهناك من النحويين الاوائل مَنْ يُسبب التعليل اليه، فمنهم عبد الله بن ابي اسحاق الحضرمي (ت 117 هـ) فهو : أول من بعَّج

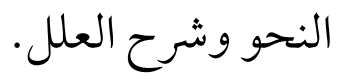


2. عدم تعصب النحاة الأوائل لما يرونه من علل نحوية كما عند الخليل رحمه الله إذ إنّه يرى انّ ما علله من علل هو من حدس أفكاره وربيا فاته التعليل الصحيح. 3. العلة أصل من الأصول الأساسية في الدرس النحوي العربي، لا سيا عند الخليل وسيبويه والمبرد قبل أنْ يتأثر بالتعليل المنطقي بتأثير الثقافة الأجنبية على العقل العربي. 4. كان الجندي يبتعد عن التكلف في اختيار العلل التي يعتل بها من غير تعصب أو تحيز على الرغم من كونه يميل إلى المذهب البصري. 5. اعمل الجندي القياس في تعليلاته فكان القياس واحداً من العوامل التي يرجح بسبه اختياره لعلة ما على علة أخرى. 6. كان الجندي يرد على العلل التي تعلل بها بعض النحاة لأن الرأي الذي اختاره مرجوح أو ضعيف ومن ثم تسقط عنه العلة تبعاً لسقوط أو ضعف الوجه والر أي. 7. تابعَ المطرزي في الغالب الأعم وهذا ما نبه عليه مرارًا، وهذا الامر شائع وكثير في الكتاب وأكثر مثّا يمصى في هذه الوريقات. 8. كان يدافع عن المصنف فيما يبدو أنه نقص، ويحاول أنْ يقوي ما علل به المطرزي من علل وآراء. 9 و. خالف الجنديُّ المطرزيَّ في بعض الأحيان؛ لكنه كان يوضح الأسباب التي دعته إلى هذه المخالفة، وكانت

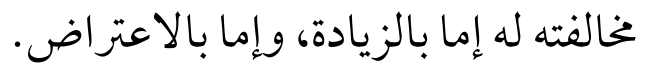

\section{الههوامش:}

(1) أبو الفضل، جمال الدين ابن منظور الأنصاري.لسان العرب ، ط3، 471/11. دار صادر، 1414هـ .بيروت. وينظر: أبو الحسين،

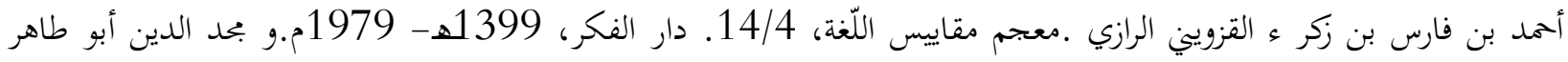

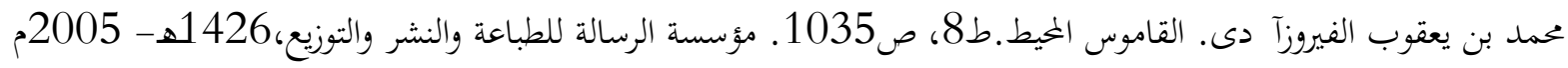

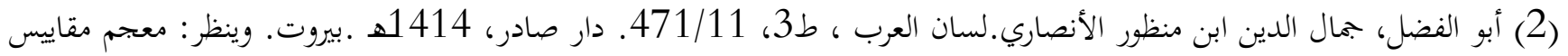


(3) أبو الفضل، جمال الدين ابن منظور الأنصاري. لسان العرب، ط3، 472/11، مادة (علل). دار صادر، 414 له. بيروت.

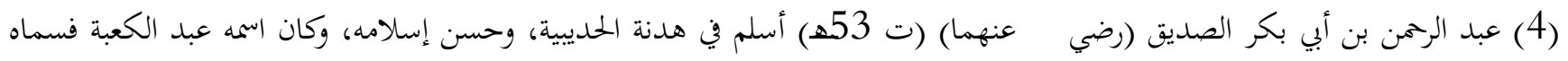

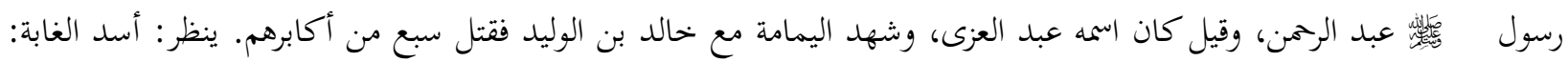

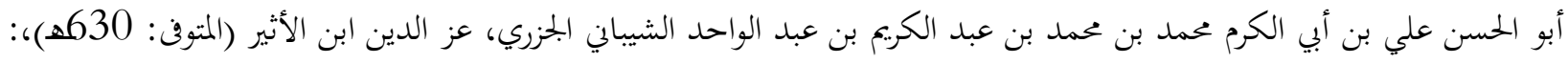

$$
.365-362 / 3
$$

(5) أبو الفضل ، جمال الدين ابن منظور الأنصاري.لسان العرب ، ط3، 471/11. دار صادر، 1414هـ ـبيروت.

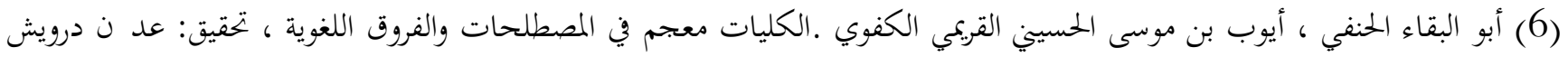
- محمد المصري ، ص630. مؤسسة الرسالة ، بيروت.

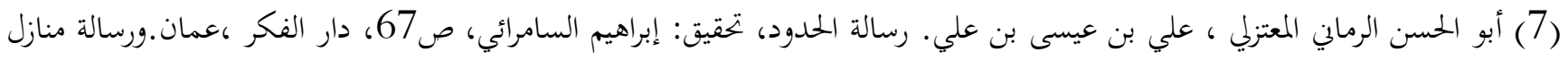

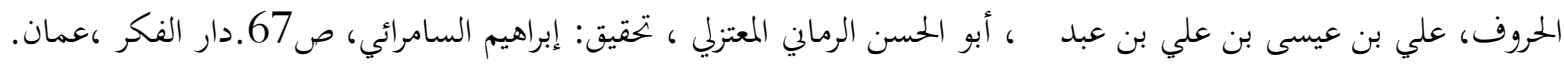

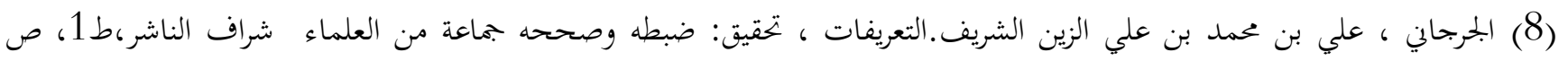
125،دار الكتب العلمية ، لبنان.

(9) الدكتور مازن المبارك .النّحو العربي العلّة النّحوية، نشأهما وتطورها، ص90.

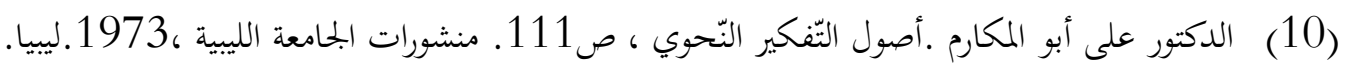

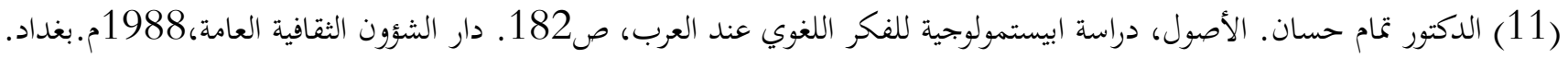

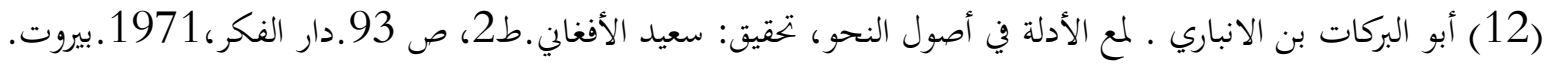
(13) (13) المصدر السابق: ص: 123.

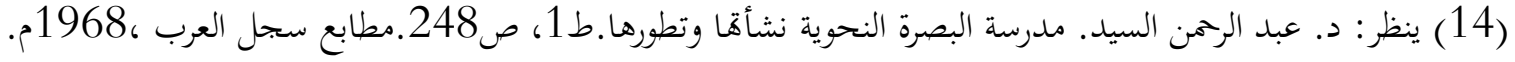

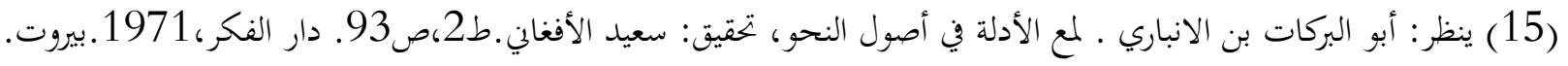

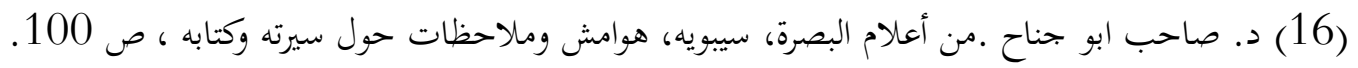

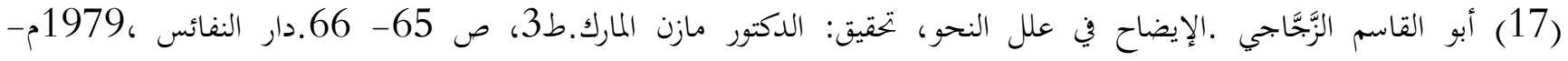
1399 ه. بيروت.

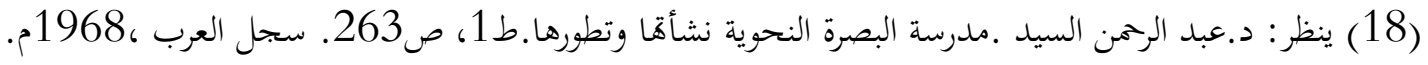

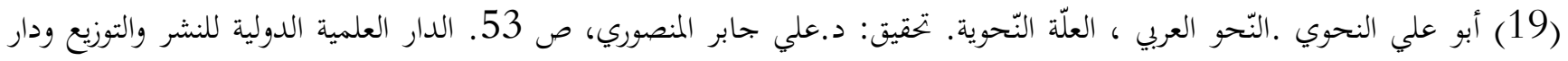
الثقافة للنشر والتوزيع ، 2002م.الاردن.

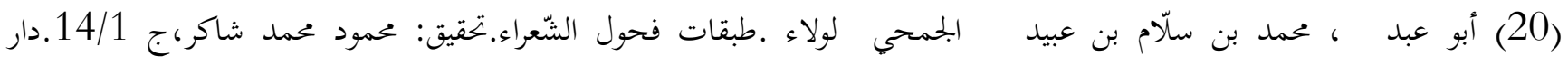

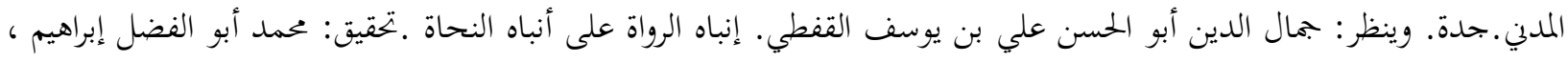

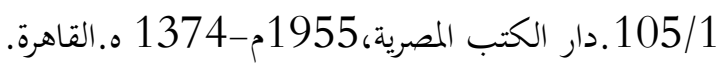


(21) أبو البركات، عبد الرممن بن محمد بن عبيد الأنصاري. نزهة الألباء في طبقات الأد ء. تحقيق: إبراهيم السامرائي ،ط3،

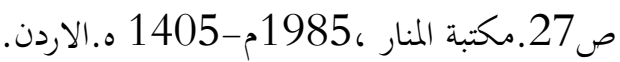
(22) جلال الدين السيوطي ، عبد الرمن بن أبي بكر.بغية الوعاة في طبقات اللغويين والنحاة .تحقيق: محمد أبو الفضل إبراهيم، 181/2 المكتبة العصرية. بيروت.

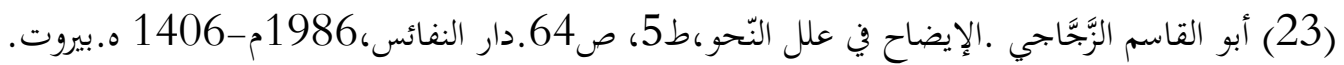

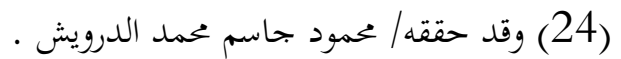
(25) وقد حقق هذا الكتاب/ الدكتور صبيح التميمي. (26) وقد حقق هذا الكتاب/ الدكتور عبد الإله النبهان.

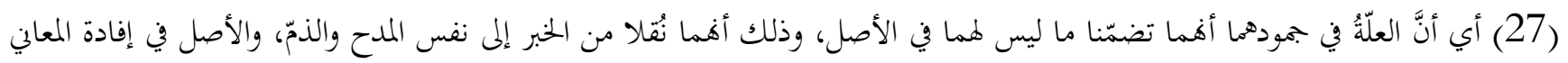

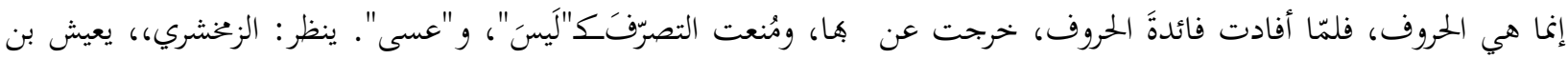

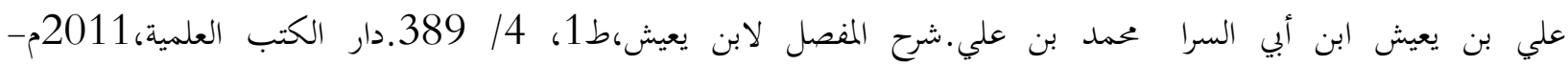
1422 ه.بيروت. بين.

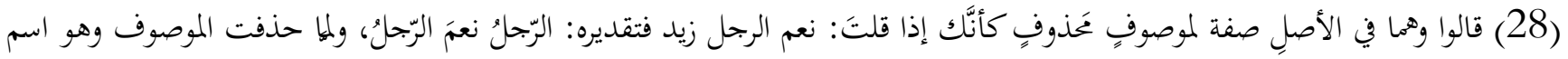

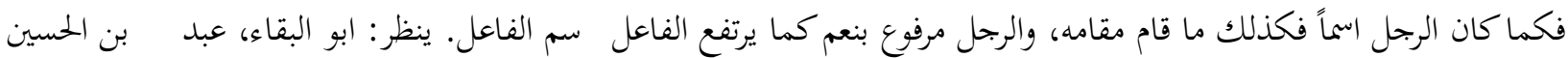

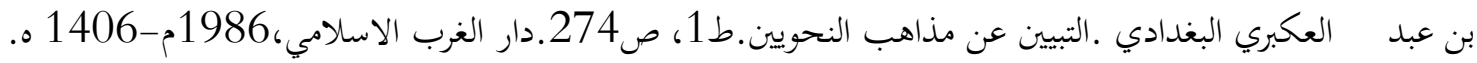
(29) لوجوه تسعة: ينظر: أبو حيان الأندلسي .التذييل والتكميل.ط1، 10/ 10 / 70 .دار القلم.دمشق.

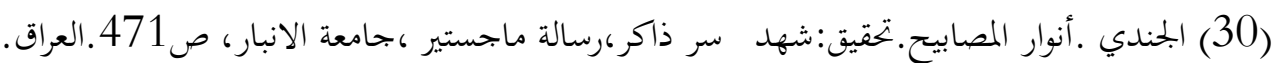

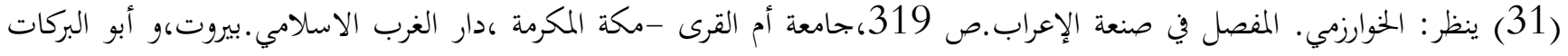

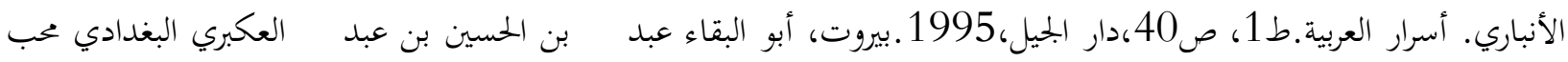

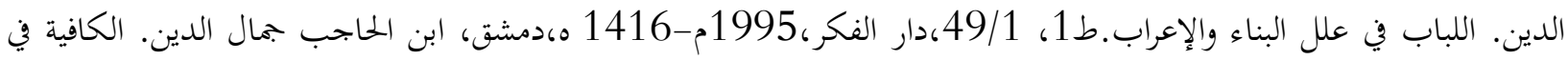

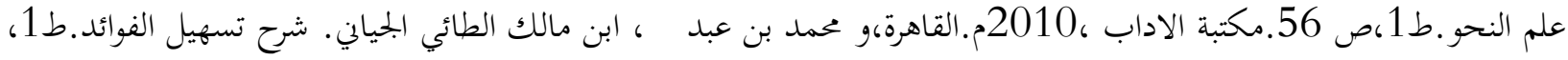

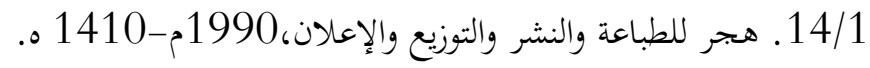

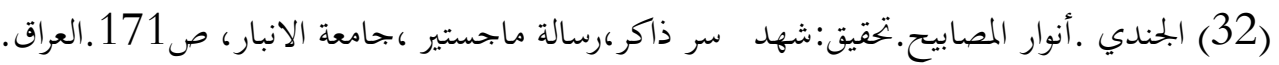

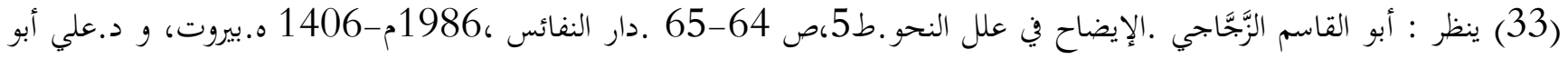

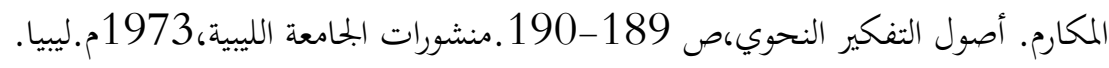

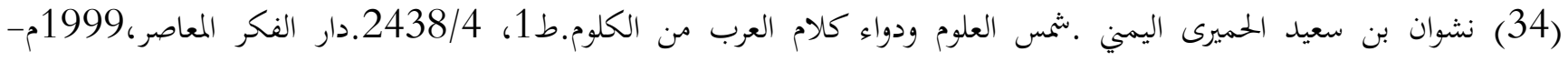
1420 ه. بيروت

(35) التعارض: هو تقابل الحجتين المتساويتين في القوة على وجه يوجب كل منهما ضد ما توجبه الأخرى في عحل واحد في وقت واحد،

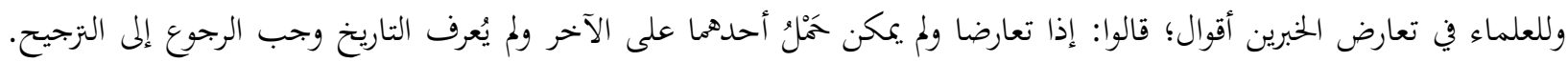


واختلفوا فيهما إذا تعارضا من غير ترجيح؛ فعند الجمهور: يطرحان وقد يستعملان على جهة التخيير إن أمكن. وقيل: لا ييجوز

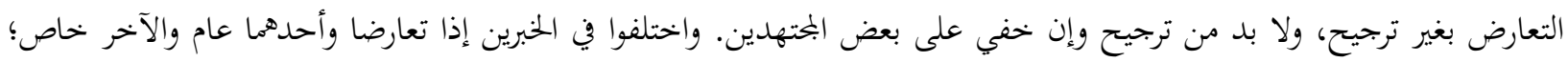

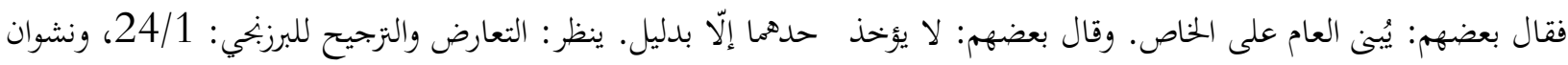
بن سعيد الحميرى اليمين .شمس العلوم ودواء كلام العرب من الكلوم.ط1، 4508/7. دار الفكر المعاصر، 1999م-

1420 ه.بيروت

(36) الجندي.أنوار المصابيح.تحقيق: شهد سر ذاكر،روسالة ماجستير جامعة الانبار، ص506.العراق.

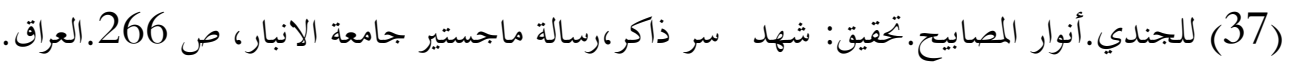

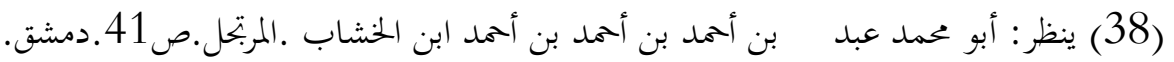

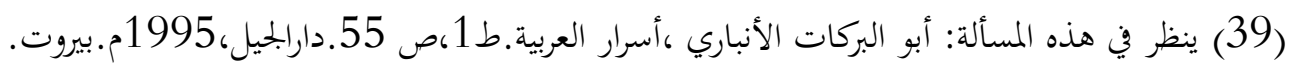

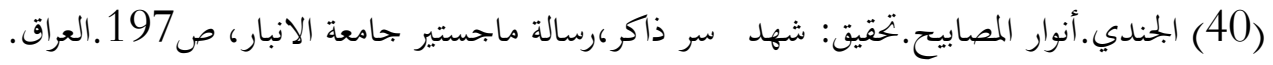

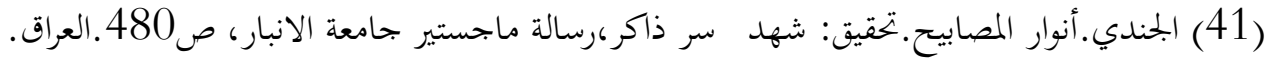

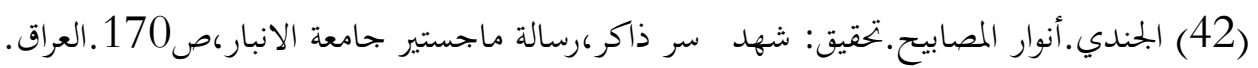
(43) ينظر: سيبويه. شرح كتاب سيبويه.ط1، 13/ 184 184، الخابني.

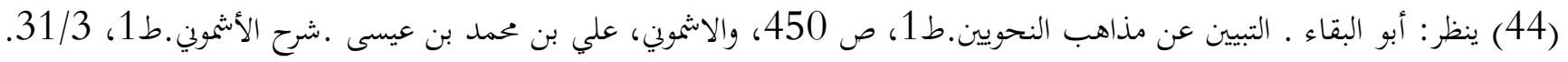

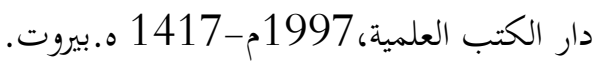
(45) ينظر : أبو البقاء ـ التبيين عن مذاهب النحويين.ط1 ، ص ص 451. 45ار الغرب الاسلامي.

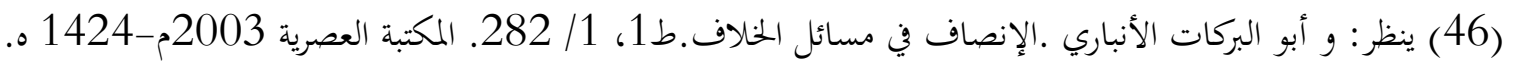
(47)ـف" " حرفان والميم المشددة كذلك،وخصوا الميم؛ لأها تقع زائدة في أواخر الأسماء نحو:" زرقم " و " ستهم " و " دلقم ".ينظر: سيبويه. شرح كتاب سيبويه.ط3، 11 / 184. الخابخي.

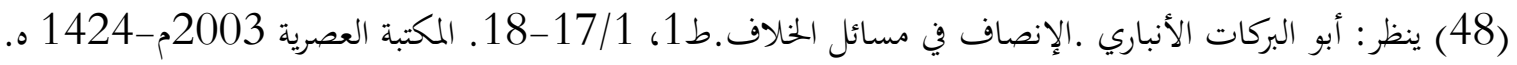

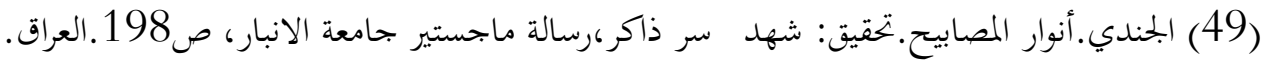
(50) ينظر: و أبو البركات الأنباري .الانصاف في مسائل الخلاف بين النحويين: البصريين والكوفيين.ط1، 19/1 وما بعدها. المكتبة العصرية 2003م-1424.

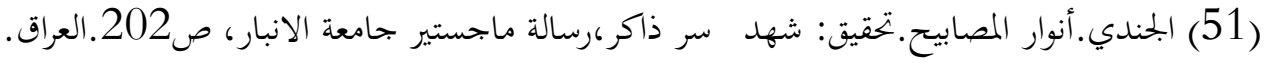

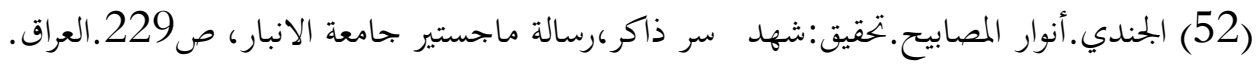

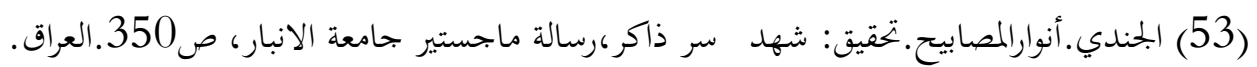

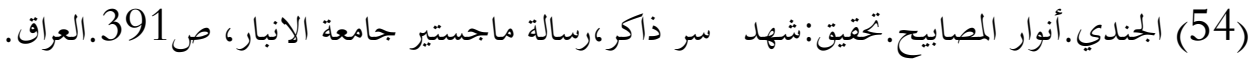

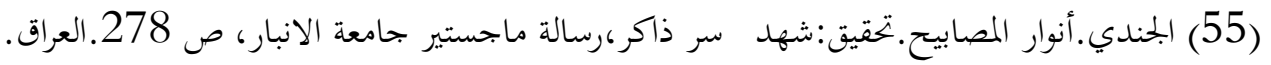

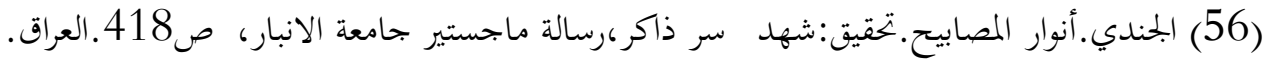


(57) قال : وأما حاشا فليس سم، ولكنه حرفُ يجر ما بعده كما بجر حتى ما بعدها، وفيه معنى الاستثناء. وبعضُ العرب يقول: ما أ بن

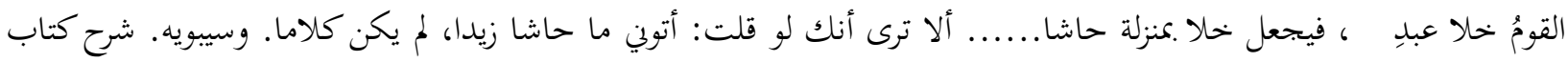

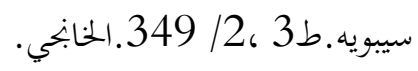
(58) هي عند المبرد وابن جين والكوفيين فعل. ينظر: أبو حيان الأندلسي .التذييل والتكميل. ط1، 8 / 314.دار القلم . دمشق،

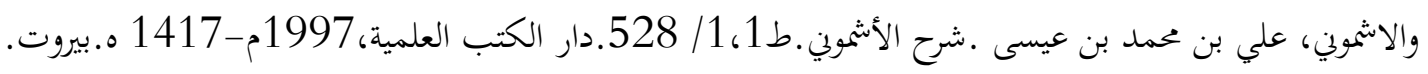

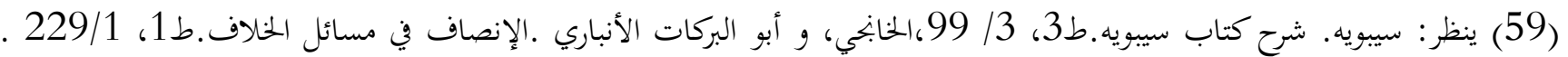

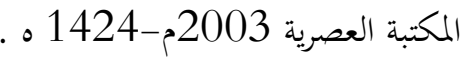
(60) ينظر: أبو علي الفارسيّ. المسائل الحلبيات.ط1، ص 244، دار القلم للطباعة والنشر والتوزيع- دار المنارة للطباعة والنشر والتوزيع،1987م-1407 ه.بيروت، وأبو البقاء ـ التبيين عن مذاهب النحويين.ط1، ص: 413. دار الغرب الاسلامي ، و أبو

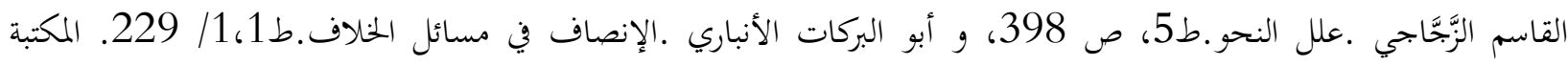

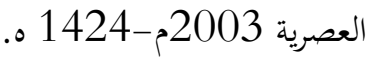

(61) ينظر: أبو البقاء ـ التبيين عن مذاهب النحويين.ط1، ص: 413. دار الغرب الاسلامي، و أبو العباس .الانتصار لسيبويه على

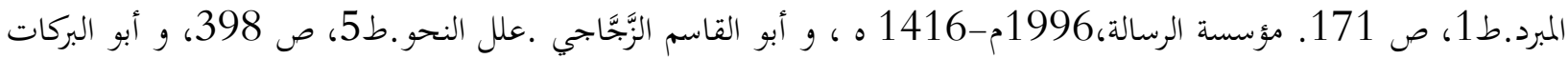

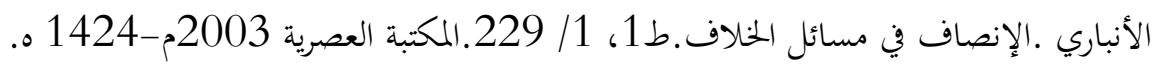

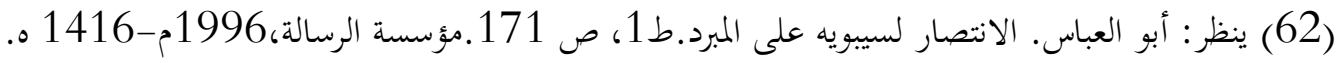

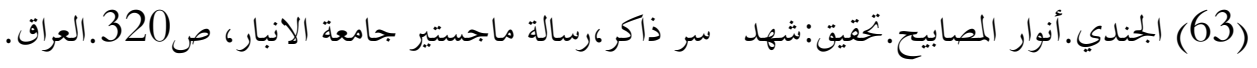

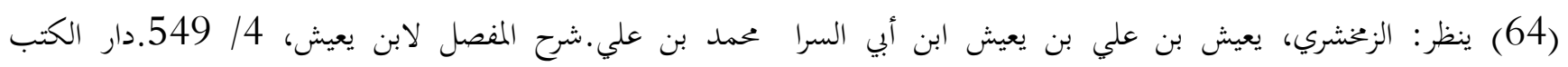

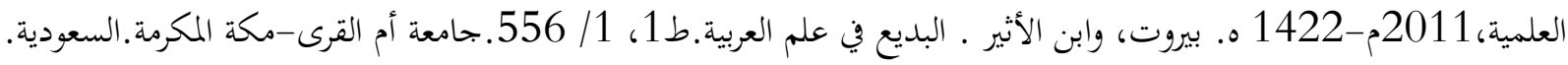

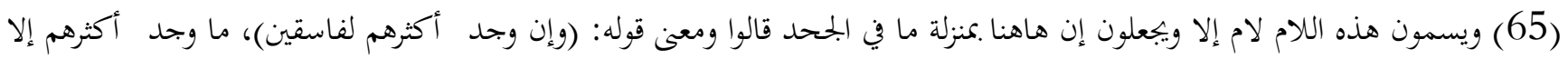
فاسقين، وكذلك قوله: (وإن كنت من قبله لمن الغافلين) ويله عندهم: ماكنت من قبله إلا من الغافلين. ينظر: أبو الفداء. الكناثش في في النحو والصرف.2/ 143،المكتبة العصرية للطباعة والنشر.بيروت، قال الزجاجي: "وهذا غلط لأن اللام لإيجاب والتحقيق وما للنفي فلا يجوز اجتماعهما في حال فيكون الكالام محققا منفيا". ينظر: أبو القاسم، عبد الرحمن بن إسحاق البغدادي النهاوندي

$$
\text { الزجاجي. اللامات.ط2، ص 114.دار الفكر .دمشق. }
$$

(66) وهو مذهب سيبويه والأخفش سعيد بن مَسْعَدة والأخفش عليُّ بن سليمان وأكثر نحاة بغداد. ينظر: أبو حيان الأندلسي .التذييل

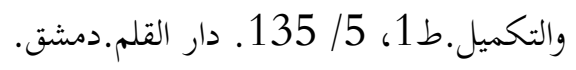

(67) لأن لام الابتداء لا يعمل ما قبلها فيما بعدها، فإن عمل لم تكن وقتئذ لام ابتداء. (68) ينظر: أبو البركات الأنباري، عبد الرحمن بن محمد بن عبيد الأنصاري .الإنصاف في مسائل الخلاف.ط1،

$$
\text { العصرية، 2003م-1424. }
$$

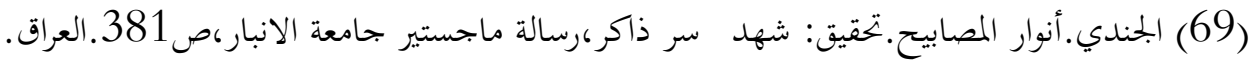




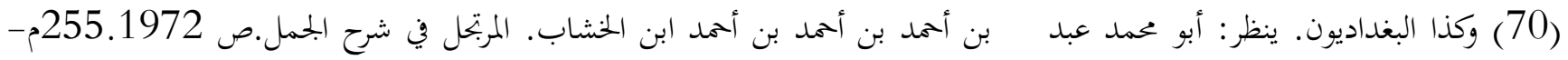

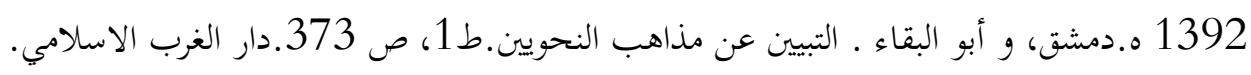

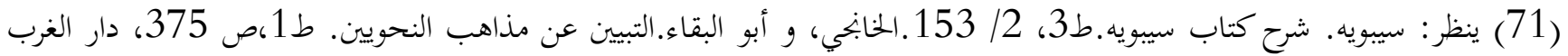

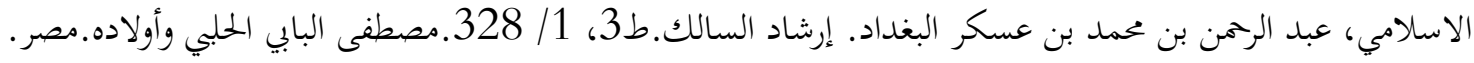

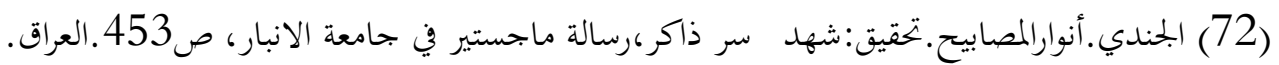

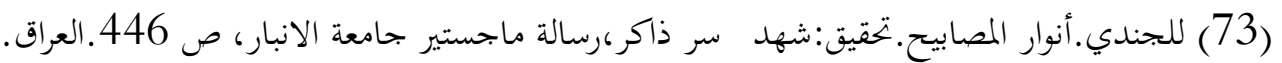

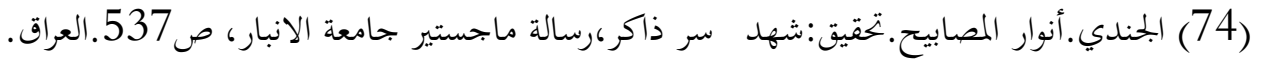

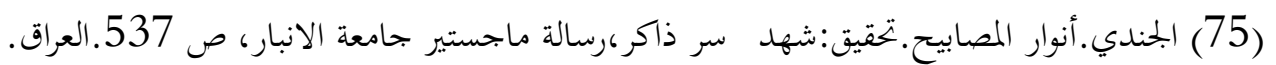

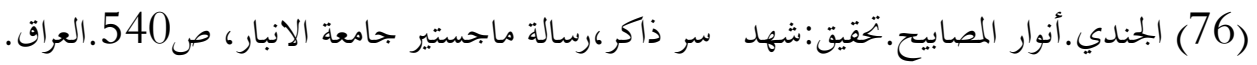

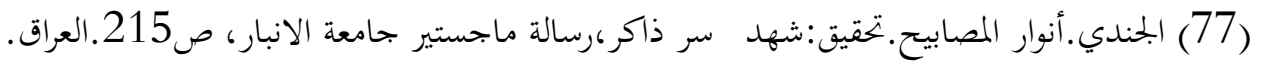

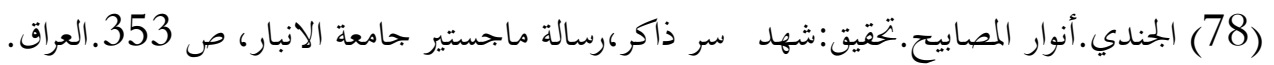

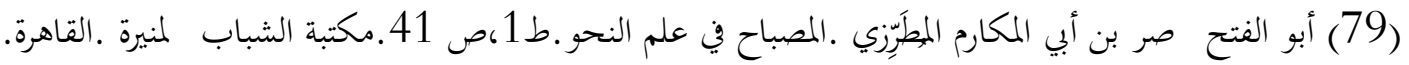

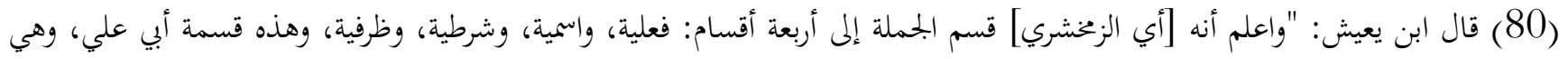

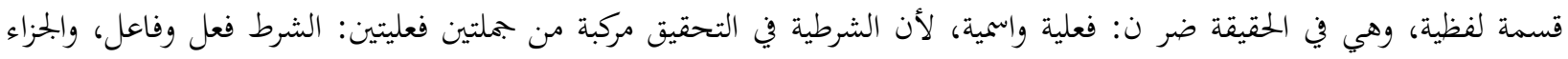

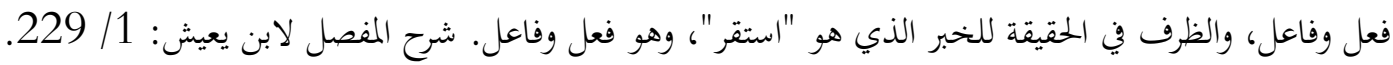
(81) (81) أي: لا تحاوز. (82) الجندي.أنوار المصابيح.تحقيق:شهد سر ذاكر،رسالة ماجستير جامعة الانبار، ص 187.العراق. 